\title{
Resilience and restoration of tropical and subtropical grasslands, savannas, and grassy woodlands
}

Elise Buisson $^{1 *}{ }^{\oplus}$, Soizig Le Stradic ${ }^{2,3}$, Fernando A. O. Silveira ${ }^{4}$, Giselda Durigan ${ }^{5}$, Gerhard E. Overbeck ${ }^{6}$, Alessandra Fidelis ${ }^{3}$, G. Wilson Fernandes ${ }^{7}$, William J. Bond ${ }^{8}$, Julia-Maria Hermann ${ }^{9}$, Gregory Mahy ${ }^{2}$, Swanni T. Alvarado ${ }^{10}$, Nicholas P. Zaloumis ${ }^{11}$ and Joseph W. Veldman ${ }^{12}$

${ }^{1}$ Institut Méditerranéen de Biodiversité et d'Ecologie marine et continentale (IMBE), Université d'Avignon et des Pays de Vaucluse, CNRS, IRD, Aix Marseille Université, Agroparc BP61207, Avignon 84911 cedex 9, France

${ }^{2}$ Gembloux Agro-Bio Tech, Biodiversity and Landscape unit, University of Liege, Gembloux 5030, Belgium

${ }^{3}$ Universidade Estadual Paulista (UNESP), Instituto de Biociências, Departamento de Botânica, Lab of Vegetation Ecology, Av. 24A, 1515, Rio

Claro, SP 13506-900, Brazil

${ }^{4}$ Departamento de Botânica, Universidade Federal de Minas Gerais, Belo Horizonte, MG 30161-901, Brazil

${ }^{5}$ Laboratório de Ecologia e Hidrologia Florestal, Floresta Estadual de Assis, Instituto Florestal, PO box 104, Assis, SP 19802-970, Brazil

${ }^{6}$ Departamento de Botânica, Universidade Federal do Rio Grande do Sul, Porto Alegre, RS 91501-970, Brazil

${ }^{7}$ Ecologia Evolutiva e Biodiversidade, Universidade Federal de Minas Gerais, Belo Horizonte, MG 30161-901, Brazil

${ }^{8}$ Department of Biological Sciences, University of Cape Town and South African Environmental Observation Network, NRF, Rondebosch, 7701, South Africa

${ }^{9}$ Restoration Ecology, Center of Life and Food Sciences Weihenstephan, Technische Universität München - TUM, Freising, Germany

${ }^{10}$ Universidade Estadual Paulista (UNESP), Instituto de Geociências e Ciências Exatas, Departamento de Geografia, Ecosystem Dynamics

Observatory, Av. 24A, 1515, Rio Claro, SP 13506-900, Brazil

${ }^{11}$ Department of Botany, University of Cape Town, P/Bag X3, Rondebosch, 7701, Cape Town, South Africa

${ }^{12}$ Department of Ecosystem Science and Management, Texas A EM University, College Station, TX 77843-2138, U.S.A.

\begin{abstract}
Despite growing recognition of the conservation values of grassy biomes, our understanding of how to maintain and restore biodiverse tropical grasslands (including savannas and open-canopy grassy woodlands) remains limited. To incorporate grasslands into large-scale restoration efforts, we synthesised existing ecological knowledge of tropical grassland resilience and approaches to plant community restoration. Tropical grassland plant communities are resilient to, and often dependent on, the endogenous disturbances with which they evolved - frequent fires and native megafaunal herbivory. In stark contrast, tropical grasslands are extremely vulnerable to human-caused exogenous disturbances, particularly those that alter soils and destroy belowground biomass (e.g. tillage agriculture, surface mining); tropical grassland restoration after severe soil disturbances is expensive and rarely achieves management targets. Where grasslands have been degraded by altered disturbance regimes (e.g. fire exclusion), exotic plant invasions, or afforestation, restoration efforts can recreate vegetation structure (i.e. historical tree density and herbaceous ground cover), but species-diverse plant communities, including endemic species, are slow to recover. Complicating plant-community restoration efforts, many tropical grassland species, particularly those that invest in underground storage organs, are difficult to propagate and re-establish. To guide restoration decisions, we draw on the old-growth grassland concept, the novel ecosystem concept, and theory regarding tree cover along resource gradients in savannas to propose a conceptual framework that classifies tropical grasslands into three broad ecosystem states. These states are: (1) old-growth grasslands (i.e. ancient, biodiverse grassy ecosystems), where management should focus on the maintenance
\end{abstract}

* Address for correspondence (Tel.: +33 490843858; Fax.: +33 490843807; E-mail: elise.buisson@univ-avignon.fr). 
of disturbance regimes; (2) hybrid grasslands, where restoration should emphasise a return towards the old-growth state; and (3) novel ecosystems, where the magnitude of environmental change (i.e. a shift to an alternative ecosystem state) or the socioecological context preclude a return to historical conditions.

Key words: forest and landscape restoration, invasive species, prescribed fire, rangeland management, secondary grassland, tropical grassy biomes, woody encroachment.

\section{GONTENTS}

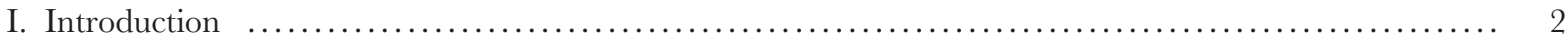

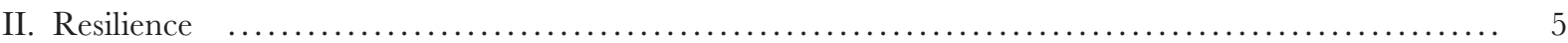

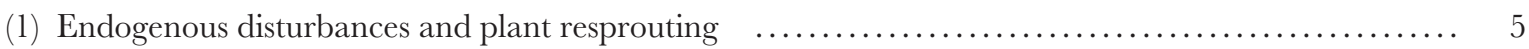

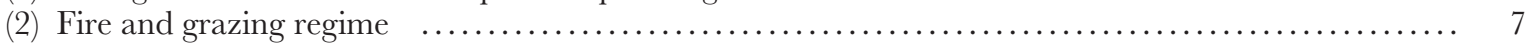

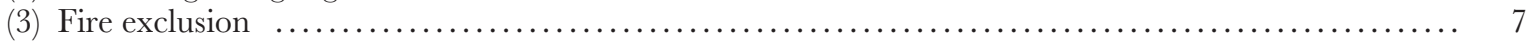

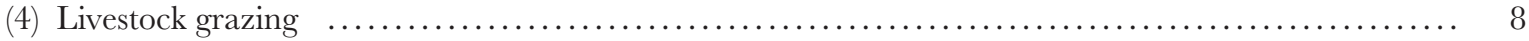

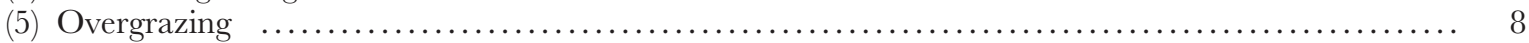

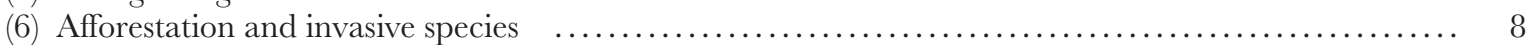

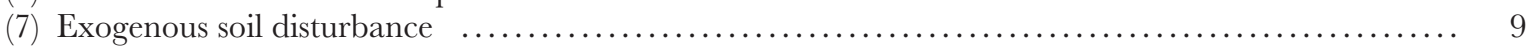

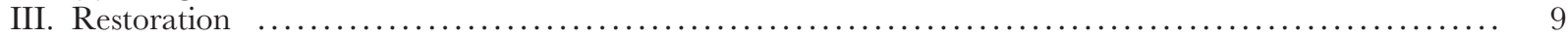

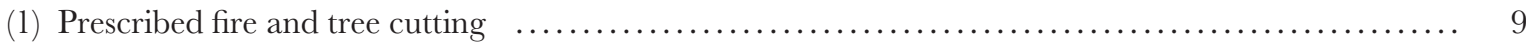

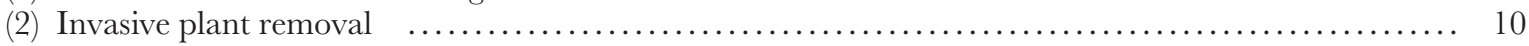

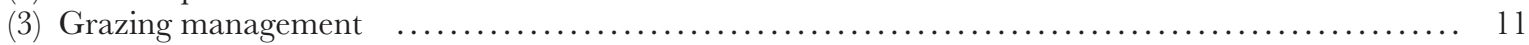

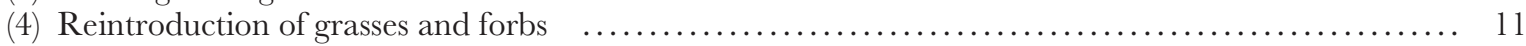

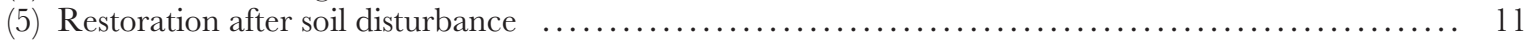

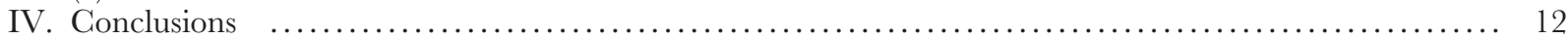

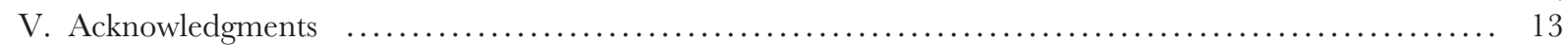

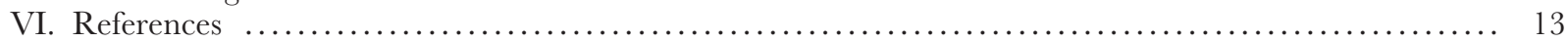

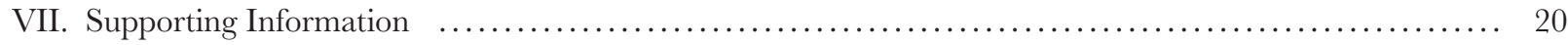

\section{INTRODUGTION}

Grasslands, broadly defined, including savannas with scattered trees and open-canopy grassy woodlands, cover approximately 52 million $\mathrm{km}^{2}$, approximately $40 \%$ of global land surface (White, Murray \& Rohweder, 2000; Gibson, 2009; Dixon et al., 2014), and approximately 20\% of the tropics (Parr et al., 2014; Bond, 2016). Across the globe, and particularly in the humid tropics and subtropics, ancient and biodiverse grassland ecosystems have long been misinterpreted as early successional vegetation, formed by human-caused deforestation (Bond \& Parr, 2010; Joshi, Sankaran \& Ratnam, 2018). In light of such misinterpretations, it is increasingly clear that to achieve biodiversity conservation goals, ecologists, environmental policymakers, and ecosystem managers should clearly distinguish old-growth grasslands (Veldman et al., 2015a) from the low-diversity grass-dominated vegetation that is created by humans (i.e. planted pastures, derived savannas; Veldman, 2016).

Old-growth grasslands are ancient grassy ecosystems characterised by species-diverse herbaceous plant communities that are maintained by frequent fires, megafaunal herbivores, and edaphic factors that limit tree growth (Veldman et al., 2015a). Old-growth grasslands occur worldwide, but those that occur in the humid tropics and subtropics (henceforth 'tropical old-growth grasslands') warrant particular conservation attention (Parr et al., 2014). Tropical old-growth grasslands exhibit exceptional biodiversity, including high species richness and endemism, and provide important ecosystem services, including belowground carbon storage, soil stabilisation, ground and surface water recharge, forage production for domestic livestock and native game animals, and habitat for native charismatic and endangered animals [e.g. elephant, Loxodonta africana and bison, Bison bison (Fuhlendorf et al., 2009; Resende, Fernandes \& Coelho, 2013; Parr et al., 2014; Hempson, Archibald \& Bond, 2015; Veldman et al., 2015a,b; Bond, 2016; Abreu et al., 2017)].

During the past century, while the global area of human-created grass-dominated vegetation increased (due to forest clearing), the world's old-growth grasslands dramatically declined due to land-use change. The decline in old-growth grasslands has been caused by widespread agricultural conversion, afforestation, and forest expansion, as well as mining and urbanisation (White et al., 2000; Nosetto, Jobbagy \& Paruelo, 2005; Lark, Salmon \& Gibbs, 2015; Noss et al., 2015; Veldman et al., 2015b). Moreover, many remaining old-growth grasslands are being degraded by altered fire regimes (i.e. changes to the historical frequency, intensity, and seasonality of fire), invasive species, overgrazing, loss of native megafauna, liming, nitrogen deposition, and elevated atmospheric carbon dioxide, which 
promotes grassland encroachment by woody plants (White et al., 2000; Weigl \& Knowles, 2014; Bond, 2016; Stevens et al., 2016).

Our knowledge of tropical old-growth grassland resilience (i.e. resistance to degradation and capacity for recovery; Hodgson, McDonald \& Hosken, 2015) and restoration (i.e. intentional activities that initiate or accelerate the recovery of an ecosystem; SER Working Group, 2004) remains limited relative to our knowledge of temperate grasslands. In many temperate regions, grassland conservation values are well recognised (Leopold, 1949; Packard, Mutel \& Jordan, 2005; Silva etal., 2008; Bond \& Parr, 2010), grassland resilience has been extensively studied (Grime et al., 2000; Jentsch et al., 2011), and grassland restoration efforts are widely promoted (Gibson, 2009). Consequently, many effective techniques to restore temperate grasslands have been developed (Perrow \& Davy, 2002; Jordan, 2005; Kiehl et al., 2010; Freudenberger \& Gibson-Roy, 2011; Török et al., 2011; Aronson, 2013; Marshall, Williams \& Morgan, 2015). By contrast, recognition of the conservation values of tropical old-growth grasslands has only emerged recently (Overbeck et al., 2007, 2013, 2015; Bond \& Parr, 2010; Laurance et al., 2011; Parr et al., 2014; Fernandes, 2016; Lehmann \& Parr, 2016; Ratnam et al., 2016; Silveira et al., 2016), or where concern has existed, conservation emphasis has been placed on the management of populations of charismatic animals (African megafauna) or agricultural conversion (e.g. Ratter, Ribeiro \& Bridgewater, 1997), rather than ecosystem restoration (but see Fernandes, 2016; Strassburg et al., 2017).

Further contributing to a lack of grassland restoration research, conservation agendas for the tropics have largely focused on forests (Overbeck et al., 2015; Searchinger et al., 2015; Bond, 2016; Veldman, 2016). Indeed, a key motivation for this review is to clarify, in light of the Forest and Landscape Restoration movement (e.g. Chazdon et al., 2017), that ecological restoration of tropical grasslands rarely involves planting trees, suppressing fire, excluding large herbivores, or applying soil fertilizers - i.e. the suite of forest-restoration strategies that are commonly misapplied to tropical old-growth grasslands (Ratnam et al., 2016; e.g. Gonçalves et al., 2013; Reis et al., 2016). We specifically aim to provide policymakers and practitioners with basic information on the kinds of activities (e.g. prescribed fire, tree cutting) that should be incorporated into large-scale restoration planning, as a means to conserve and restore biodiverse tropical grasslands.

To demonstrate the need for such information, in August 2017, we searched Restoration Ecology, the primary international ecology journal focused on restoration research [using the search function of Wiley Online Library (Wiley, 2017)] for the terms "tropical grassland", "subtropical grassland", and savannah AND tropic* in the title, key words, or abstract of articles published from 1993 to 2017. The search returned 14 articles, of which only eight were relevant to grassland restoration (see online Appendix S1, Table S1 in File S1). The same search using the term "tropical forest" yielded 109 articles. As further evidence that tropical grassland restoration research is lacking, the Global Partnership on Forest and Landscape Restoration (GPFLR, 2016), perhaps the most influential consortium of institutions promoting large-scale restoration in the tropics, offers very little information on restoration strategies for savannas and grasslands. Clearly, there is a great need to better integrate theoretical knowledge of tropical grassland ecology with management practice to conserve and restore these ecosystems.

This is not to say that conservationists have completely ignored tropical grasslands, indeed some tropical old-growth grasslands are recognised for their biodiversity and have elicited conservation concern (Strassburg et al., 2017). For example, the grasslands of the Cerrado (Brazil), tropical Andes, and mountains of eastern Africa are recognised as biodiversity hotspots - i.e. regions of high conservation priority, based on high diversity and endemism as well as a high proportion of land conversion (Mittermeier et al., 2011). Still, many other diverse and threatened tropical grasslands are not classified as biodiversity hotspots and receive little conservation attention. Examples of under-recognised grasslands include: Southern African Montane Grasslands, Guianan Lowland Grasslands and Savannas (Mittermeier etal., 2011; Dixon etal., 2014), Southern Central Africa edaphic grasslands (Faucon et al., 2016), subtropical grasslands of southern Brazil (Overbeck et al., 2007), subtropical savannas of North America (Noss etal., 2015), and savannas of India and southeast Asia (Ratnam et al., 2016). Unfortunately, even with better recognition, we should not expect classification of more grasslands as biodiversity hotspots to halt conversion for agriculture (Machado et al., 2004; Carvalho, De Marco \& Ferreira, 2009) or prevent forest expansion (e.g. Durigan \& Ratter, 2016). As more tropical old-growth grasslands are lost, grassland restoration should increase in importance as part of efforts to maintain biodiversity and ecosystem services (Resende et al., 2013; Parr et al., 2014; Bond, 2016; Fernandes, 2016).

Herein, we review current research and identify knowledge gaps that must be filled to improve our understanding of the resilience of tropical old-growth grasslands and to improve our ability to restore tropical grassland biodiversity (Mace, 2014; Oliver et al., 2015). Indeed, a key part of restoration planning is to consider the resilience of ecosystem states to environmental change and management interventions (Hobbs \& Norton, 1996; Mitchell et al., 2000; Hirst et al., 2003; Belyea, 2004; Lockwood \& Samuels, 2004; Suding, Gross \& Houseman, 2004; White \& Jentsch, 2004; Hobbs, Jentsch \& Temperton, 2007; Briske et al., 2008; Hobbs \& Suding, 2013). We restrict our review to grasslands of the humid tropics and subtropics $\left(<35^{\circ}\right.$ latitude) that receive $>750 \mathrm{~mm}$ mean annual precipitation (Fig. 1 and see online Fig. S1); these are regions where climate can permit the development of both grasslands and forests (Hirota et al., 2011; Lehmann et al., 2011; Staver, Archibald \& Levin, 2011). Whereas the herbaceous plant community of arid tropical grasslands tend to be composed of annual and 


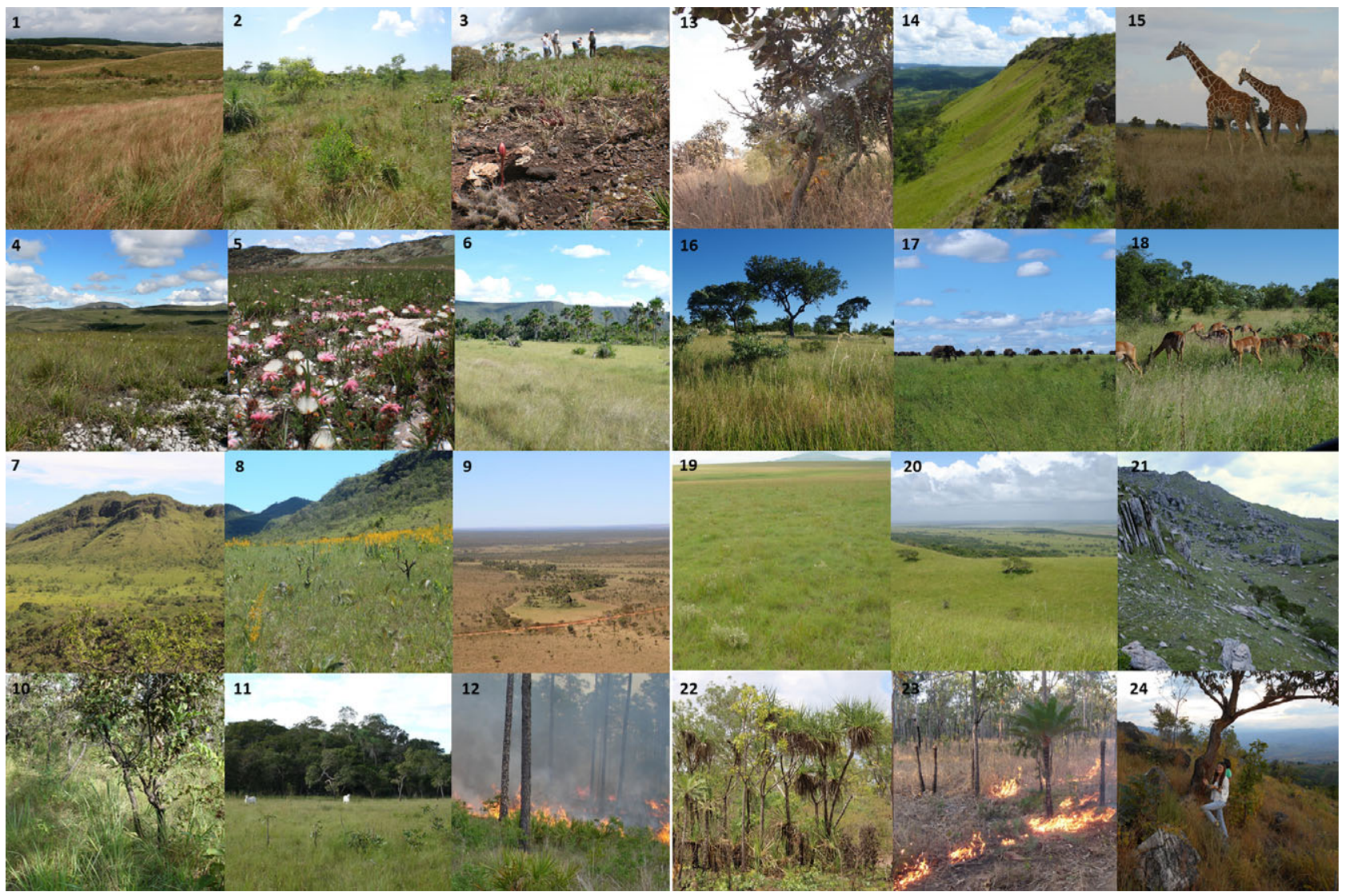

Fig. 1. Images of tropical and subtropical old-growth grasslands, savannas, and grassy woodlands with numbers on the images corresponding to the numbered geographical locations shown in online Appendix S2 in File S1, Fig. S1). (1) Subtropical grasslands (campos sulinos) in Rio Grande do Sul, Brazil. (2) Cerrado moist grasslands in São Paulo, Brazil. (3) Cangas grasslands, on ironstone outcrops in the Iron Quadrangle, Brazil. (4) Campo rupestre grasslands, southeastern Brazil. (5) Campo rupestre grasslands a few months after fire, southeastern Brazil. (6) Cerrado grasslands in Tocantins (vereda), Brazil. (7, 8) Cerrado in Goiás (campo sujo), Brazil. (9) Cerrado grasslands in Tocantins (campo sujo and vereda), Brazil. (10) Cerrado in eastern lowland Bolivia. (11) Cattle in grassland-forest mosaic Bolivia. (12) Prescribed fire in a subtropical pine savanna, southern USA. (13) Miombo, Uapaca kirkina savanna, Congo. (14) Katanga copper outcrops, Congo. (15) Savanna in Kenya. (16-18) Savanna in Kruger National Park, South Africa. (19) Montane grasslands, South Africa. (20) Coastal grasslands South Africa. (21) Tapia (Uapaca bojeri) savanna and quartzic grasslands on Ibity mountain, Madagascar. $(22,23)$ Pandanus, cycads and Eucalyptus savanna, Northern Territory, Australia. (24) High-elevation savanna, southwest China; also see Ratnam et al. (2016) for Asia.

short-lived perennial species, old-growth grasslands of the humid tropics are typically composed of long-lived perennial grasses and forbs (Bond \& Zaloumis, 2016); for this reason, our review focuses primarily on the ecology of perennial grassland plants.

Unlike arid grasslands, where climate severely constrains woody plant growth, the ecological characteristics and biodiversity of humid tropical grasslands are maintained through interactions among disturbances (i.e. fire and herbivory) and soil characteristics (i.e. hydrology, soil depth, toxic concentrations of heavy metals, Fig. 2; Langan et al., 2017). In Figure 2, we depict how disturbance frequency and edaphic constraints on tree growth interact to determine where tropical old-growth grasslands occur. Of particular note, this model (Fig. 2) highlights the continuum from edaphic old-growth grasslands (i.e. on soils that preclude the development of dense tree cover) to disturbance-dependent old-growth grasslands (i.e. on soils that can support either grassland or forest depending on fire and herbivory). Disturbance-dependent grasslands are of critical conservation and restoration importance because of their susceptibility to exclusion of fire and herbivores (Noss et al., 2015; Durigan \& Ratter, 2016), as well as their suitability for agriculture (i.e. on fertile soils and with ample precipitation; Searchinger et al., 2015) or for mining (i.e. metal-rich soils; Pena et al., 2017).

To offer a schematic representation of our findings, we produced a conceptual model (Fig. 3) that integrates ecological theory (depicted in Fig. 2) with restoration activities for tropical grasslands. In Figure 3, we adapted conceptual models of the novel ecosystem concept from Hobbs et al. (2009) to tropical grasslands. The novel ecosystem concept provides a framework for understanding ecological resilience and alternative stable state theory in 


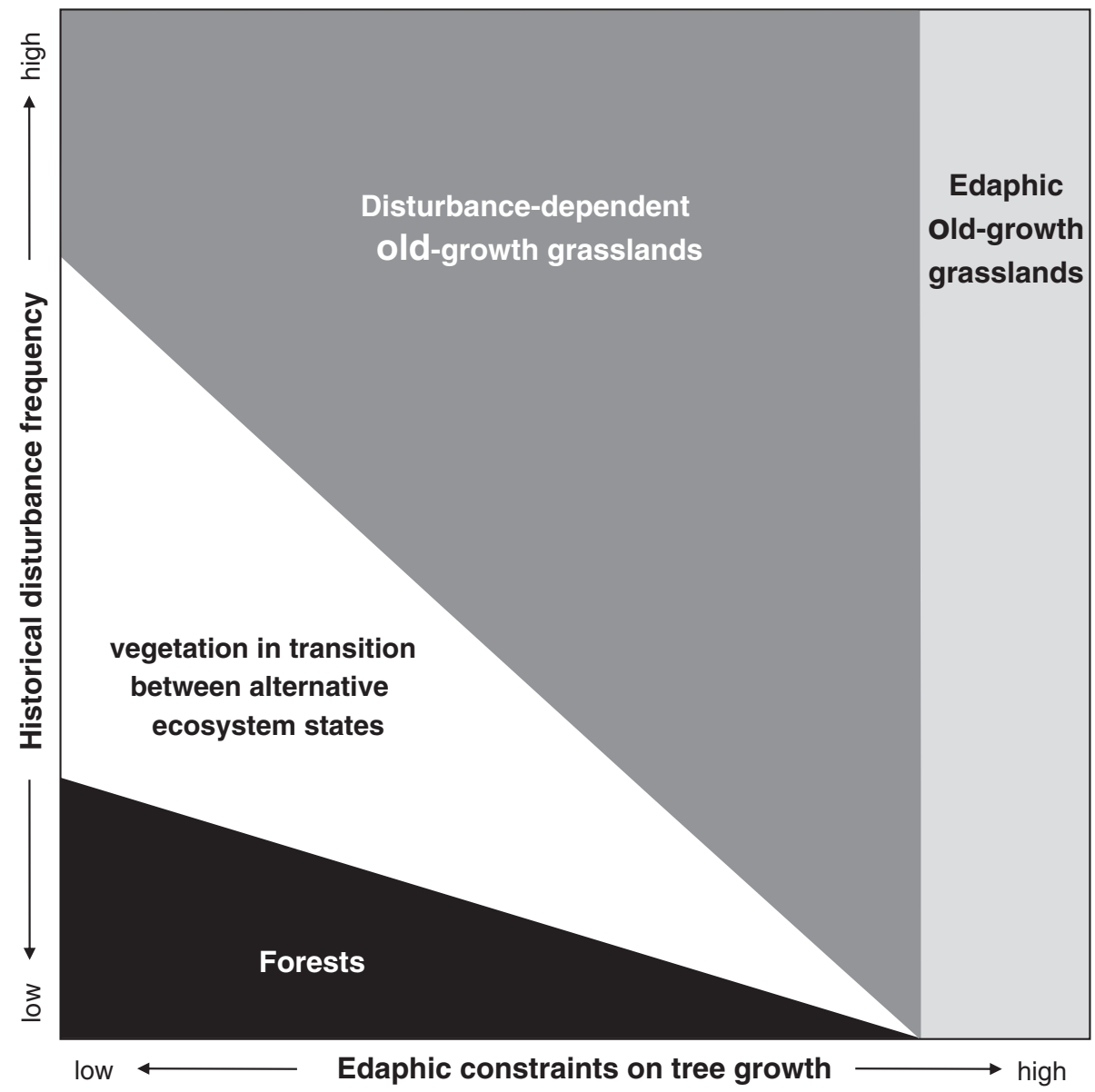

Fig. 2. Ecosystem state space occupied by tropical old-growth grasslands in regions where precipitation is sufficient for the development of forests (Bond, Woodward \& Midgley, 2005; Hirota et al., 2011; Staver et al., 2011). On most soil types, the existence of disturbance-dependent grasslands is determined by interactions between soils and endogenous disturbances, especially fire (Hoffmann et al., 2012; Murphy \& Bowman, 2012; Noss, 2013; Lehmann et al., 2014; Hempson et al., 2015; Dantas et al., 2016; Langan, Higgins \& Scheiter, 2017). In edaphic grasslands, poor drainage (seasonally saturated or inundated soils), extremely low moisture-holding capacity (shallow, rocky soils), or exceptionally low soil fertility preclude dense tree cover, even in the absence of frequent disturbances (Noss, 2013; Le Stradic et al., 2018b). In forests, dense tree cover constrains fire frequency and grazer abundance by limiting herbaceous plant productivity. The unlabelled state space between disturbance-dependent old-growth grasslands and forests represents unstable vegetation (fire excluded, tree-encroached grassland) in transition between alternative ecosystem states (Van Langevelde et al., 2003).

the context of restoration (Suding et al., 2004), with potential to inform management decisions (Hulvey et al., 2013). In this model, we also incorporated the old-growth grassland concept to refer to the historical or reference ecosystems that should guide tropical grassland restoration (Veldman et al., 2015a). To support these conceptual models, below we discuss the ecology of tropical old-growth grasslands, divided into two sections on resilience and restoration.

\section{RESILIENGE}

\section{(1) Endogenous disturbances and plant resprouting}

Most tropical old-growth grasslands are highly resilient to, and even dependent on, frequent fires and/or native megafaunal herbivores, which maintain grassland plant diversity and vegetation structure [i.e. low tree cover (Coutinho, 1990; Bond \& Keeley, 2005; Cingolani, Noy-Meir \& Díaz, 2005; Veldman et al., 2015a; Bond, 2016)]. These endogenous disturbances (sensu McIntyre \& Hobbs, 1999) are part of the evolutionary history and internal dynamics of tropical grasslands and should not be confused with the sorts of exogenous disturbances - often imposed by humans - that cause shifts to alternative ecosystem states (e.g. Fig. 3A, B).

Vegetation-fire and vegetation-herbivore feedbacks are key to understanding endogenous disturbances in tropical grasslands (e.g. Dantas \& Pausas, 2013; Fill et al., 2015; Hempson et al., 2015). Herbaceous plants, grasses in particular (e.g. Simpson et al., 2016), produce the fine fuel that promotes grassland flammability and provides 


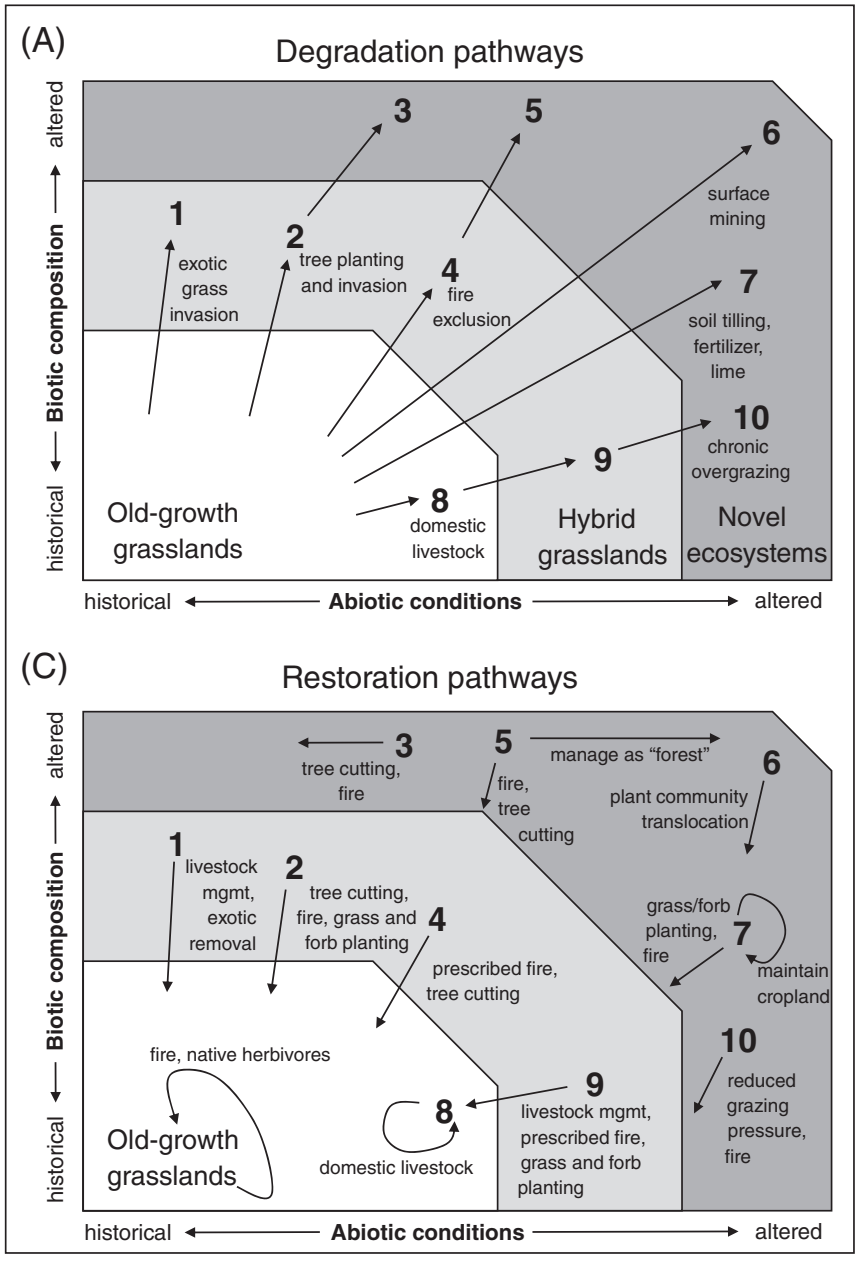

Disturbance-dependent grasslands
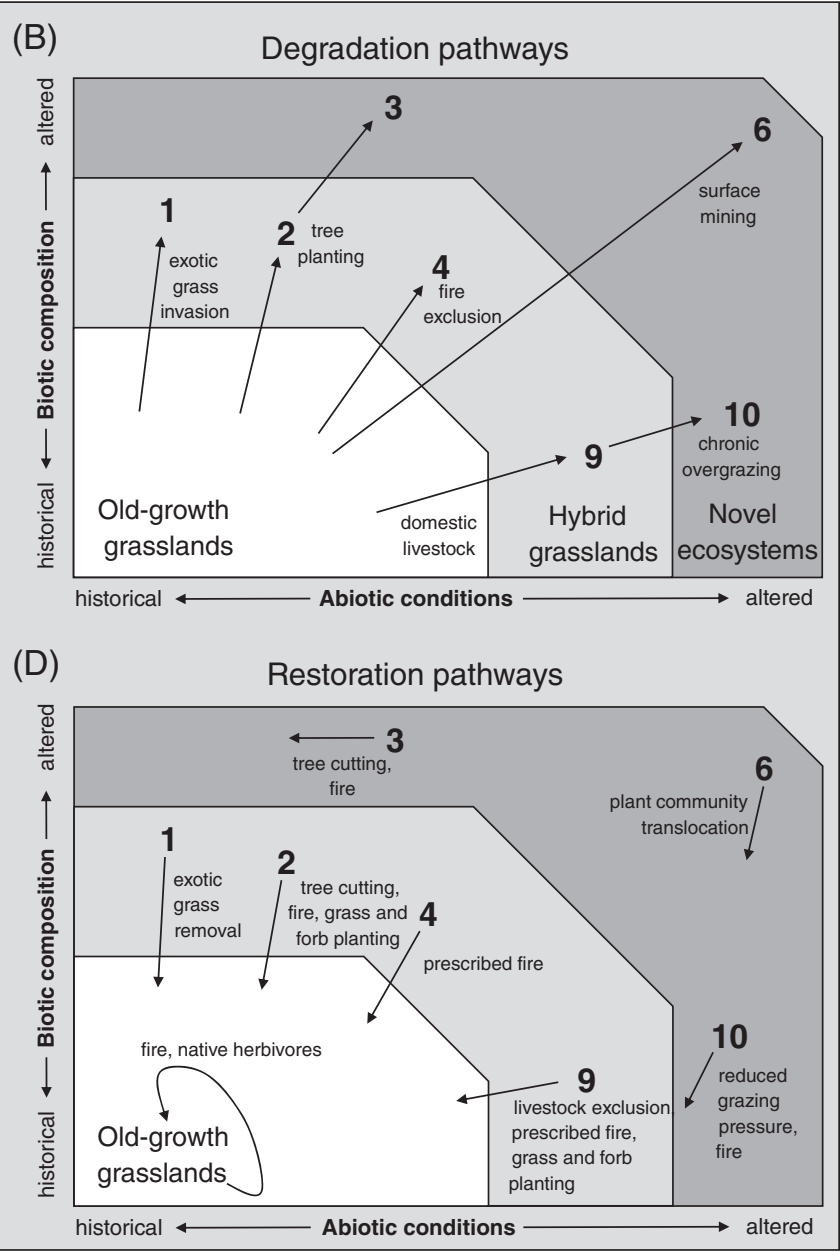

Edaphic grasslands

Fig. 3. (A, B) Common ecosystem state transitions (i.e. degradation pathways), and (C, D) management interventions (i.e. potential restoration pathways), for tropical grasslands. Disturbance-dependent grasslands (A, C, white box) and edaphic grasslands (B, D, grey box) are depicted separately, due to differences in resilience and restoration potential (see Fig. 2). Numbers represent the qualitative position of ecosystem states in relation to historical abiotic and biotic variables. Novel ecosystem states face strong biotic, abiotic and/or socioeconomic barriers to restoration. Hybrid ecosystems may be restored toward the reference (old-growth grassland) state, although full recovery likely requires many decades to centuries. Old-growth grasslands, the reference (historical) ecosystem states (Veldman et al., 2015a), typically require frequent fire and/or domestic or native herbivores to maintain biotic composition and abiotic conditions. We adapted these diagrams to tropical grasslands from Hobbs, Higgs \& Harris (2009).

forage for grazing herbivores; in some savannas, highly flammable tree litter (e.g. Pinus spp.; Platt et al., 2016) is also critical to ecosystem flammability. In turn, fire and herbivores interact to restrict tree cover and woody encroachment that can otherwise limit the productivity of the herbaceous plant community (e.g. Veldman, Mattingly \& Brudvig, 2013; Fig. 1). Many, if not most, tropical old-growth grassland plants have evolved to endure disturbances that remove aboveground biomass, including recurrent fires and herbivory (Bond \& Keeley, 2005; Veldman et al., 2015a; Bond, 2016; Pausas, 2017) by investing in underground storage organs (USOs; Simon et al., 2009; Maurin et al., 2014; Pausas et al., 2018) and bud banks (near or below the soil surface) that allow resprouting after loss of aboveground biomass (Coutinho, 1990; Brewer \& Platt, 1994a,b; Appezzato-da-Glória et al., 2008; Fidelis, Lyra \& Pivello, 2013).

Appreciation for herbaceous plant regeneration strategies is critical to understanding tropical old-growth grassland resilience to endogenous versus exogenous disturbances. Resprouting - i.e. vegetative regeneration of aboveground organs from roots, stems, or persistent bud banks - not seeding, is the principal manner by which grasslands regenerate from fire and herbivory (Coutinho, 1990; Bond \& Midgley, 2001; Clarke et al., 2013). By contrast, severe human-caused soil disturbances (e.g. tilling, surface mining) destroy belowground plant organs, thus killing whole plants and eliminating the possibility of resprouting (Kirkman 
et al., 2004; Ostertag \& Robertson, 2007; Brudvig et al., 2013; Zaloumis, 2013; Ilunga wa Ilunga et al., 2015; Vieira et al., 2015). Reproduction from seed clearly plays a role in old-growth grassland plant population dynamics (Keeley \& Fotheringham, 2000; Medina \& Fernandes, 2007), but few old-growth tropical grassland plant populations rely on persistent seed banks for post-fire regeneration (Duvigneaud \& Denaeyer-De Smet, 1963; Overbeck et al., 2005; Overbeck \& Pfadenhauer, 2007; Kolbek \& Alves, 2008; Lamont \& Downes, 2011; Fidelis et al., 2012). Instead, many species flower profusely (Conceição et al., 2013; Fidelis \& Blanco, 2014) after resprouting from bud banks, and then produce seeds, most of which never establish (Overbeck et al., 2006; Dayamba et al., 2008, 2010; Neves \& Conceição, 2010; Fichino et al., 2012, 2016; Le Stradic et al., 2015; Delhaye et al., 2016; Fidelis, Daibes \& Martins, 2016).

Low rates of seedling establishment among tropical old-growth grassland plants, even after fire, is perplexing, given that fire-stimulated flowering likely evolved as a means to focus investment in reproduction during post-fire periods (Brewer et al., 2009), periods when otherwise limiting nutrients are most available (e.g. phosphorus; Butler et al., 2018) and conditions are most favourable for establishment from seed (e.g. due to reduced competition; Myers \& Harms, 2011). Although poor establishment from seed may simply be due to severe environmental constraints on seedlings (e.g. water stress, in hot, sunny grasslands) or a trade-off between investment in plant persistence and seed production, studies among long-lived resprouting shrubs, in recurrent-fire Mediterranean-type ecosystems, point towards the accumulation of somatic mutations as a cause of low fecundity (Lamont \& Wiens, 2003). This hypothesis, which remains to be tested in grasses and forbs of the humid tropics, posits that since most somatic mutations result in deleterious alleles, poor seed quality is an inherent cost of evolving the capacity to resprout repeatedly over long periods of time (Wiens \& Slaton, 2012).

Whatever the reason for low seedling establishment, the reliance of long-lived tropical old-growth grassland plants on USOs and bud banks to survive fires and herbivory (Bond \& Midgley, 2001; Pausas et al., 2018), and their contrasting low resilience to human-induced soil disturbances, highlights the need to distinguish endogenous disturbances that occur above ground (e.g. fire) from exogenous disturbances that alter soil structure (e.g. tilling). Whereas numerous studies deal with tropical grassland resilience to endogenous disturbances (e.g. post-fire recovery), few address community resilience to exogenous disturbances. Keeping the endogenous versus exogenous distinction in mind, below we discuss tropical old-growth grassland resilience to various forms of environmental change.

\section{(2) Fire and grazing regime}

Endogenous disturbances (i.e. fire, herbivory) are thought to maintain tropical old-growth grassland plant diversity by limiting competitively dominant herbaceous species, preventing woody encroachment, stimulating reproduction, and creating recruitment opportunities (Beckage \& Stout, 2000; Overbeck et al., 2005; Brewer et al., 2009; Myers \& Harms, 2011; Fidelis et al., 2012; Müller et al., 2012; Scott etal., 2012; Andrade etal., 2015; Abreu et al., 2017). The resilience of tropical old-growth grasslands to human-altered grazing and fire regimes is highly dependent on ecosystem type and site-specific conditions. In general, disturbance-dependent grasslands, with moderate to high soil water and nutrient availability, can tolerate more intense grazing for longer durations (Müller et al., 2012; Fedrigo et al., 2018) relative to edaphic grasslands, where soil conditions severely constrain plant productivity and regeneration (Kolbek \& Alves, 2008; Fig. 3A, B). Similarly, the frequency of fire required to prevent woody encroachment (Hoffmann et al., 2012) and maintain plant diversity (Veldman et al., 2014) increases along resource availability gradients, from resource-poor (edaphic) grasslands to resource-rich (disturbance-dependent) grasslands (Fig. 2). Although the frequency of fire required for the maintenance of grasslands depends on soils and interactions with herbivores, both disturbance-dependent and edaphic old-growth tropical grasslands appear quite resilient to frequent fire (Andersen et al., 2005). Indeed, Le Stradic et al. (2018b) found that plant community composition in two distinct edaphic grasslands did not differ with fire history, and that after fire, both grasslands rapidly recovered their aboveground biomass.

\section{(3) Fire exclusion}

Fire exclusion can eliminate many characteristic herbaceous plant species from old-growth tropical grassland communities due to litter accumulation or competitive exclusion by dominant grasses, shrubs, or trees (Uys, Bond \& Everson, 2004; Overbeck et al., 2005; Hiers et al., 2007; Fidelis et al., 2012, 2013; Scott et al., 2012; Veldman et al., 2013; Abreu et al., 2017; Fig. 3A). In the short term, fire exclusion can lead to increased fire intensity, due to the accumulation of biomass that would have historically been consumed in more frequent, lower intensity fires (Batista et al., 2018). Over longer time scales (i.e. many years to decades), fire exclusion results in forest expansion (i.e. woody encroachment leading to forest formation in former grassland; Oliveira \& Pillar, 2004; Parr, Gray \& Bond, 2012; Durigan \& Ratter, 2016), the loss of herbaceous grassland species (Hiers et al., 2007; Brooks, Setterfield \& Douglas, 2010; Parr et al., 2014; Abreu et al., 2017; Fig. 3A, B), and reduced ecosystem flammability, as flammable grasses are replaced by fire-impeding forest tree species (Kane, Varner \& Hiers, 2008; Kreye et al., 2013; Veldman et al., 2013; Fill et al., 2015). Conversely, human-initiated fire management (implemented to increase visibility for hunting or to improve forage production), which is highly dependent on the local socio-cultural context (Alvarado et al., 2015), can result in fires that are more frequent or intense compared to historical fire regimes [e.g. through a change from cool burning, 
wet-season, lightning fires to hotter fires in the dry season (Ramos-Neto \& Pivello, 2000; Rissi et al., 2017; Alvarado, Silva \& Archibald, 2018)]. Given the high rates of woody encroachment in grasslands globally, the high resprouting capacity of old-growth grassland plants, and the dependence of grassland biodiversity on fire, we contend that increased fire frequencies are of far less concern for tropical grassland resilience relative to fire exclusion (Andersen et al., 2005; Parr et al., 2014; Durigan \& Ratter, 2016). That said, where altered fire regimes result in more-intense fires, they can threaten fire-sensitive components (e.g. small groves of trees) embedded in grassland landscapes (Trauernicht et al., 2012; Coelho et al., 2018). Studies on the resilience of tropical grasslands to these new fire regimes (Drewa, Platt \& Moser, 2002; Andersen et al., 2005; Ribeiro \& Figueira, 2011; Alvarado et al., 2012, 2014; Russell-Smith et al., 2013; Fernandes, 2016) suggest that fire-management decisions should account for landscape-scale heterogeneity in vegetation and incorporate local knowledge to deliver maximum social and ecological benefits.

\section{(4) Livestock grazing}

Old-growth grasslands vary widely in their resilience to domestic livestock grazing (e.g. Cingolani et al., 2005). Grasslands that occur on infertile soils and did not evolve with megafaunal herbivores appear to be the least resilient to domestic grazers (Fig. 3B) (Milchunas, Sala \& Lauenroth, 1988; Cingolani et al., 2005). The campos rupestres of Brazil are an example of such a system where shallow soils and shallow-rooted plants are very sensitive to trampling (Kolbek \& Alves, 2008). In other grasslands, typically with higher soil fertility, domestic livestock may be important to the maintenance of biodiversity by functioning as a surrogate for fire or by mimicking the effects of native herbivores (Boldrini \& Eggers, 1996; Blanco et al., 2007; Overbeck et al., 2007). Indeed, literature on grasslands that are resilient to moderate cattle grazing (Mcintyre, Heard \& Martin, 2003; Fig. 3A, C) attribute this resilience to a long evolutionary history with either extant native megaherbivores (e.g. Africa) or recently extinct Pleistocene megafauna (Frost, 1993; Ratter et al., 1997; Miller, 2005; Overbeck et al., 2007; Noss, 2013). Where wild herbivores and livestock co-occur, management to minimise direct competition for forage can foster positive (facilitative) interactions between wild and domestic herbivores, while also maintaining grassland structural heterogeneity and associated biodiversity (Riginos et al., 2012; Fynn et al., 2016). Grazers can dramatically reduce aboveground grass biomass, thereby altering grassland fire spread and intensity (Trauernicht et al., 2013), thus complicating the relationship between livestock and the maintenance of grassland ecosystem functioning. Given that elevated atmospheric carbon dioxide appears to be shifting the competitive balance between $\mathrm{C}_{4}$ grasses and $\mathrm{C}_{3}$ trees and shrubs (Collatz, Berry \& Clark, 1998; Bond \& Midgley, 2012), and that grazers further alter grass - tree interactions through effects on ecosystem flammability (Case \& Staver, 2016), more research is needed on the contribution of livestock as a driver of woody encroachment in old-growth grasslands of the humid tropics and subtropics.

\section{(5) Overgrazing}

Overgrazing occurs when grazing intensity, frequency, and duration exceeds site-specific thresholds (i.e. shifting an old-growth or hybrid grassland to a novel ecosystem state; Fig. 3A, B). Such shifts are typically characterised by dramatic changes in both abiotic (e.g. soil compaction or erosion) and biotic (e.g. species composition) components of ecosystems (Fig. 3A, B). Among the most well-documented biotic consequences of mismanaged livestock on plant communities, overgrazing can cause exotic grazer-tolerant grasses or unpalatable native species to increase in abundance (Crowley \& Garnett, 1998; Fensham, 1998; Andrade et al., 2015).

Savanna tree cover, a common metric used in forestry and remote-sensing studies, responds very differently to grazing compared to the herbaceous plant community (Stevens et al., 2016). As such, when planning grassland restorations, it is necessary to look to the herbaceous plant community, rather than just trees (Brudvig et al., 2014; Veldman, 2016). Likewise, remote-sensing vegetation indices, such as normalised difference vegetation index (NDVI) and enhanced vegetation index (EVI), should be used with caution to detect ecosystem state changes in tropical grasslands, because these indices do not distinguish native from exotic grasses (but see Zlinszky et al., 2015). That said, time-series remote-sensing data on tree and shrub cover at global and regional scales can be quite useful to monitor grazer-mediated woody encroachment, particularly where grassland fire regimes have been altered. Indeed, among key research needs, we must determine how best to manage domestic livestock in old-growth grasslands that occur where land-use policies restrict fire [e.g. Cerrado and subtropical grasslands (Ratter et al., 1997; Overbeck et al., 2007; Müller et al., 2012] and determine better ways to use remote sensing to detect changes in grassland plant communities (e.g. through consideration of phenology; Wilsey, Martin \& Kaul, 2018).

\section{(6) Afforestation and invasive species}

Afforestation, the establishment of tree plantations in grasslands (de Abreu et al., 2011; Zaloumis \& Bond, 2011, 2016; Veldman et al., 2015a,b), and exotic tree invasions (de Abreu \& Durigan, 2011) lead to the loss of herbaceous grassland species due to competition with trees for light and water as well as litter accumulation (Hiers et al., 2007; Brooks et al., 2010; Parr et al., 2014; Fig. 3A, B). The magnitude of plant community change with afforestation can vary widely depending on tree density and whether or not fires are excluded (Veldman et al., 2014). When tree density is high and fires are excluded for long periods of time, herbaceous plant communities decline substantially in diversity and cover (Brudvig et al., 2014). Herbaceous plants can recolonise following tree removal (Harrington, 2011; Torchelsen, Cadenazzi \& Overbeck, 2018), but post-afforestation grasslands remain compositionally different from old-growth 
grasslands (Koch et al., 2016; Zaloumis \& Bond, 2016). These secondary grasslands, like those that form after agricultural abandonment, tend to be dominated by ruderal species that are either good dispersers or that emerge from persistent seed banks. Such ruderal plant traits are markedly different from the traits of species that are characteristic of tropical old-growth grasslands (e.g. USOs; Veldman et al., 2015a).

Non-native grass invasion can represent a huge threat to tropical grasslands, due to the negative impact caused by exotic grasses on native grasses and forbs (e.g. Pivello, Shida \& Meirelles, 1999; Damasceno et al., in press; Dresseno et al., in press). In addition to suppressing native species, invasive grasses can lead to a high biomass accumulation, with consequences for fire regimes, including increased fire intensity (Mistry \& Berardi, 2005; Setterfield et al., 2010; Gorgone-Barbosa et al., 2015). Because invasive grasses can alter fire regimes and native plant community composition, they are one of the most challenging filters to overcome in restoration projects. Where fires are frequent, exotic grasses hamper native herbaceous plant establishment from seed and increase the mortality of woody species (Hoffmann \& Haridasan, 2008; Mendonça et al., 2015). Yet in the absence of fire, exotic-dominated tropical grasslands will become low-diversity forests. Indeed, across a chronosequence of abandoned pastures invaded by African grasses in Brazil, Cava et al. (2018) found that herbaceous savanna plants did not spontaneously regenerate and that fire exclusion promoted the formation of low-diversity forests, which lacked the historical old-growth savanna structure and species composition. Further complicating matters, exotic grass invasions can be promoted by cattle, which disperse seeds and influence apparent competition between native and invasive species (e.g. via soil compaction, selective grazing). Because cattle ranchers often intentionally sow seeds of non-native forage grasses in an attempt to increase grassland productivity (Parsons, 1972), restoration ecologists must consider both the biodiversity impacts of non-native species and the value attributed to them by pastoralists.

\section{(7) Exogenous soil disturbance}

Tropical grassland resilience to tillage agriculture and surface mining is extremely low, with plant community recovery ranging from slow and incomplete to non-existent. In subtropical Australia, Fensham et al. (2016) found, 60 years after cultivation, that secondary grassland plant communities had only $60 \%$ compositional similarity to nearby old-growth grasslands. In subtropical North America, Kirkman et al. (2004) found, 65 years after agriculture, that secondary pine savannas still lacked many grass and forb species typical of old-growth savanna. In South Africa, Zaloumis (2013) found, 20 years after cultivation, that secondary grasslands recovered only $25 \%$ of the species that occur in old-growth grasslands. In Brazil, Le Stradic, Fernandes \& Buisson (2018a) found, 8 years after excavation for gravel, that quarry sites had almost no grassland species, suggesting severe recruitment limitation. In mined heavy-metal grasslands in central Africa, both Faucon et al. (2011) and Ilunga wa Ilunga et al.(2015) found, 60 years after mining for heavy metals, that despite the proximity of seed sources, vegetation on mining sites remained very different, both compositionally and functionally from old-growth grasslands. Such exogenous soil disturbances destroy both above- and belowground vegetation, thus eliminating the potential for plants to persist via resprouting (Fig. 3A, B). Because old-growth grassland plants have evolved strategies (e.g. underground storage organs) to survive repeated aboveground disturbances, apparently at the cost of colonisation potential (Silcock \& Scattini, 2007; Veldman et al., 2015a; Silveira et al., 2016), grasslands on former agricultural land fail to recover their characteristic plant communities even after many decades (Kirkman et al., 2004; Brudvig et al., 2013; Vieira et al., 2015). Whereas recolonisation of characteristic old-growth grassland species is extremely limited in secondary grasslands (Silcock \& Scattini, 2007; Ilunga wa Ilunga et al., 2015; Veldman et al., 2015a; Silveira et al., 2016), many non-native invasive and native weedy species are rapid colonisers of post-agricultural grasslands due to their higher germination and better ability to establish in disturbed environments (Brudvig et al., 2014; Gorgone-Barbosa et al., 2016a). These weedy species can limit the establishment of desired old-growth grassland species (Zaloumis, 2013; Gorgone-Barbosa, 2016; Le Stradic et al., 2016), posing a huge hurdle to restoration (see also Section II.6).

In addition to killing plants, agriculture and mining can alter soil conditions to such a degree that they are no longer suitable for old-growth grassland plant communities. This can occur due to several factors, including: loss of topsoil; increased soil nutrient availability, a legacy of agricultural fertilizers that favours dominant competitors (Andrade et al., 2015; Koch et al., 2016); changes in soil heavy metal content [e.g. copper, cobalt (Leteinturier, Baker \& Malaisse, 1999; Barbosa et al., 2010; Faucon et al., 2011)]; or depletion of soil microbial communities (Bach et al., 2010). For all these reasons, the species composition of secondary grasslands that develops following agriculture or mining is very different from that of old-growth grasslands (Faucon et al., 2011; Ilunga wa Ilunga et al., 2015; Koch et al., 2016; Le Stradic et al., 2018a); full grassland community recovery in such circumstances will require many decades to several centuries (Veldman et al., 2015a; Fernandes, 2016). Consequently, we suggest that in many cases, secondary grasslands that form after abandonment of row crop agriculture, afforestation, or mining operations qualify as novel ecosystems (Fig. 3A, B). Because such novel ecosystems, by definition, cannot be restored to their historical conditions, we further suggest that the conservation of existing old-growth tropical grasslands must be a top priority in restoration planning (Veldman et al., 2015a).

\section{RESTORATION}

\section{(1) Prescribed fire and tree cutting}

Most knowledge on restoration of tropical grasslands using prescribed fire comes from studies in Australia (Scott et al., 
2012), Africa (e.g. Sawadogo, Tiveau \& Nygård, 2005; Savadogo et al., 2008, 2009; Dayamba et al., 2010; Smit et al., 2016) and the southeastern USA (Provencher et al., 2001; Walker \& Silletti, 2006). The application of prescribed fires can clearly contribute to the reduction of shrub or tree cover and re-creation of historical vegetation structure (i.e. scattered trees), but the role of fire in re-establishment and maintenance of native herbaceous plant communities is more complicated. For example, in Australia, reintroduction of fire can restore open savanna vegetation structure, but not the composition of the herbaceous layer (Scott et al., 2012). Prescribed fires can also be combined with additional treatments, including cutting and herbicide application to trees to favour herbaceous groundcover, as well as seed additions to reintroduce herbaceous plant species (Walker \& Silletti, 2006). In all cases, for fire to be effective in restoration, sufficient fuel must be present, a key challenge if the herbaceous plant community is sparse, or flammable tree litter is lacking.

In some fire-excluded savannas in the southeastern USA, tree cutting can be both unnecessary and expensive: in a restoration experiment by Provencher et al. (2001), positive effects on plant community recovery were due to the restoration of fire regime, not reduction in tree cover. Prescribed fires alone, if applied at the early stages of woody encroachment, also seem to be sufficient to restore grasslands of the North American Great Plains (Twidwell et al., 2013) and the savannas of South Africa (Booysen \& Tainton, 1984). In other cases, where tree cover is particularly dense, such as fire-excluded savanna invaded by pines, tree cutting (coupled with prescribed fire) is thought to be a prerequisite for re-establishment of savanna plant communities (de Abreu $\&$ Durigan, 2013). The extremely low recovery of Cerrado grassland plant communities after pine invasion, regardless of the restoration treatment applied (tree cutting, fire, litter removal or a combination), led de Abreu \& Durigan (2013) to conclude that a combination of treatments to reduce tree cover and pine litter must be accompanied by native plant reintroduction, if there is to be any potential for plant community restoration. We suggest that plant community restoration efforts may additionally benefit from treatments such as inoculation with soil microbial communities from old-growth grasslands (Middleton \& Bever, 2012), to restore plant-soil interactions.

While fire effects have been studied in the Cerrado (Hoffmann, 1996, 1998; Miranda, Bustamente \& Miranda, 2002), fire management is only starting to be explored more widely (Durigan \& Ratter, 2016; Rissi et al., 2017; Schmidt et al., 2017; Alvarado et al., 2018; Schmidt et al., 2018) and mostly with a focus on responses of woody plants (de Medeiros \& Miranda, 2005). A particular gap in restoration research, little is known about the role of fire in the reproduction and establishment of savanna grassland plants. Initial studies on heat shock simulated in the laboratory suggest that fire does not break seed dormancy, stimulate germination, or kill the seeds (Le Stradic et al., 2015; Fichino et al., 2016; Zupo, Baeza \& Fidelis, 2016), whereas in field experiments, although many seeds died, fire indirectly promoted germination of surviving seeds, by reducing vegetation cover, which increased soil surface temperature fluctuation (Daibes et al., 2017). In a laboratory study of grasses of southern Africa, Ghebrehiwot et al. (2009) found that exposure to liquid smoke increased germination rates of five of six species; effects of elevated temperatures had differing effects on seedling growth, suggesting that elevated post-fire temperatures may favour establishment of some species over others. More research is needed to provide precise information on what constitutes optimal fire management in plant-community restoration in different local contexts, such as in the presence of invasive species or unique soils (Driscoll et al., 2010). One aspect of fire management in restoration is clear: without fire, grasslands do not recover on abandoned agricultural lands. Instead, they develop into low-diversity forests (Veldman et al., 2014; Abreu et al., 2017; Cava et al., 2018).

\section{(2) Invasive plant removal}

In small-scale experiments $\left(1-100 \mathrm{~m}^{2}\right)$, controlling invasive species can be successful when numerous restoration techniques are combined, such as topsoil transfer, fire, and manual weeding (Fig. 3C, D, Brooks et al., 2010; te Beest et al., 2012; Castillioni, 2015; de Assis, 2017). Pilon, Buisson \& Durigan (2018) showed that in exotic grass-invaded savanna, topsoil scraping combined with native topsoil transfer effectively eliminated invasive grasses and reintroduced herbaceous plants, including endemic species. Castillioni (2015) and de Assis (2017) showed that herbicides should be applied with great caution to control Urochloa decumbens, an African grass that is invasive in Brazil, because herbicides can impair native forbs and grasses. Moreover the use of herbicides to control invasive plant species is controversial because of toxicity to people and the environment (Wittenberg \& Cock, 2001). De Assis (2017) showed that manual weeding can effectively control Urochloa decumbens; in the same experiment, fire reduced the cost of manual weeding, but fire alone was not sufficient to control grass invasion. In southern Brazil, Thomas (2017) showed that topsoil removal and herbicide application were effective in reducing cover of Urochloa decumbens from over 40\% to less than 5\% 1 year after treatment, but did not promote re-establishment of typical grassland species, even when combined with hay transfer. Establishment of an assemblage of competitive native species after eradication of invasive species is thought to be important to prevent reinvasion of restored sites (Cordero et al., 2016). Unfortunately, despite successful invasive plant control in small plots in short-term experiments, over the longer term at larger spatial scales, restorations remain prone to reinvasion (Sampaio et al., 2015).

Invasive grasses, such as Imperata cilindrica in the southern USA (Platt \& Gottschalk, 2001) and Andropogon gayanus in Australia (Rossiter et al., 2003) can increase the frequency, intensity, and spatial extent of grassland fires through production of large quantities of fine fuel. Other invasive species (e.g. Urochloa brizantha) can reduce ecosystem flammability relative to native-dominated grasslands, but this can 
depend on the fire season (Gorgone-Barbosa et al., 2015). Although fire can be effective at controlling fire-sensitive invasive species (Stevens \& Beckage, 2009; te Beest et al., 2012), fire can also promote invasive species that evolved with frequent fires (Imperata cylindrica; Lippincott, 2000) or indirectly promote invasive species by opening recruitment sites, suitable for germination (Urochloa brizantha and Urochloa decumbens; Gorgone-Barbosa et al., 2016a,b). The fire ecology of invasive species should therefore be carefully considered as part of fire management (Gorgone-Barbosa, 2016) in tropical grassland restoration.

\section{(3) Grazing management}

In a review on the restoration of land degraded by overgrazing, Papanastasis (2009) highlighted appropriate livestock management as a vital tool for restoration of ecosystems composed of species that evolved with large herbivores. One cannot substitute native wildlife for livestock and expect to maintain the same ecological processes and plant communities; grazing and browsing patterns differ among species and may change fire regimes, woody plant cover, and biogeochemical cycling (Hempson, Archibald \& Bond, 2017). Whereas livestock are incompatible with conservation of edaphic old-growth grasslands, in certain disturbance-dependent old-growth grasslands, native wildlife and/or livestock can be used to manage vegetation if manipulated adequately (Fuhlendorf \& Engle, 200 1; Joubert, Pryke \& Samways, 2017; Fedrigo et al., 2018). Further, where land-use policies restrict fire in disturbance-dependent grasslands, domestic livestock can, in some cases, serve as an imperfect surrogate for fire, by controlling the biomass of palatable dominant plants (both native or exotic) and preventing shrub and tree encroachment (Ratter et al., 1997; Overbeck et al., 2007; Müller et al., 2012). Livestock can also create establishment sites for rare plant species and can enhance the diversity of habitats across landscapes (Lunt et al., 2007). Appropriate use of livestock in tropical grassland restoration will require improved knowledge of the ecological factors that influence plant community responses to grazing and fire (Joubert et al., 2017), as well as an understanding of the contribution of livestock to local livelihoods (cessation of grazing may not be feasible if alternative income sources are not available).

\section{(4) Reintroduction of grasses and forbs}

A common objective of grassland restoration is to reintroduce plant species that have become locally extinct or to increase the abundance of desirable plant species whose populations declined due to altered disturbance regimes. In temperate grassland restoration, the most common approach to plant propagation is to sow seeds, either collected from existing populations or cultivated specifically for restoration plantings (Kiehl et al., 2010), or alternatively, to rely on seed dispersal by wind or animals, as was historically done by pastoralists (Poschlod et al., 1998). Seeds can be directly sown or introduced via hay or soil transfers, accomplished by hand or machine. Hay transfers involve cutting and collecting the herbaceous layer of temperate grasslands at a time when seeds are mature but have yet to disperse. This cut hay, with attached seeds, is then spread at the restoration site. Soil transfers involve collecting temperate grassland topsoil and then spreading this soil, along with dormant seeds contained in the soil, onto the restoration site.

For restoration of tropical grasslands, knowledge is slowly increasing about the transfer (Le Stradic, Buisson \& Fernandes, 2014a; Le Stradic et al., 2016; Pilon et al., 2018) and propagation of old-growth grassland species (Negreiros et al., 2009; Oliveira et al., 2012; Le Stradic et al., 2014b; Gomes et al., 2018), yet for most ecosystems such information remains scarce or non-existent, particularly for herbaceous species (Fernandes, 2016). Complicating matters, emerging research on species of the Cerrado, Katanga copper outcrops (Central Africa), and Queensland (Australia), suggests that many graminoids - a functional group that is critical to ecosystem flammability and livestock forage - produce few seeds, much of which is of low quality (Silcock \& Scattini, 2007; Boisson et al., 2015; Le Stradic et al., 2015; Kolb et al., 2016; Dayrell et al., 2017). As such, the opportunities for reintroduction and propagation via seed sowing, soil transfer, and hay transfer, are often extremely limited (Le Stradic et al., 2014a, 2016; but see Le Stradic et al., 2014b; Sampaio et al., 2015; Gomes et al., 2018; Pilon et al., 2018). When seeds are available, plant species introduction must often be combined with an appropriate set of treatments for them to establish (Wiseman et al., 2002; Sampaio et al., 2015; Pilon et al., 2018). In sum, due to both knowledge gaps and ecological hurdles to establishment from seed, the reintroduction of tropical grassland species remains technically difficult and expensive (Dayrell et al., 2016).

On a positive note, extensive research on the restoration of subtropical grasslands of Australia and the southeastern USA suggests that with significant investment in research and seed harvesting, reintroductions of seeds, particularly when coupled with other management techniques (e.g. prescribed fire and tree cutting, see Section III.1), can help restore grassland ecosystem services (e.g. livestock forage; Waters, Whalley \& Huxtable, 2001) and improve plant diversity and community composition (Walker \& Silletti, 2006). But, even in these well-studied grasslands, full plant community recovery to old-growth conditions cannot be achieved in short periods of time and there remain huge hurdles to the re-establishment of many species of conservation concern (Aschenbach, Foster \& Imm, 2010). Clearly, much research on population ecology, especially the germination and establishment requirements of native species of tropical old-growth grasslands, is needed.

\section{(5) Restoration after soil disturbance}

Whereas for most temperate grasslands, common site preparation includes topsoil manipulation, such as ploughing, tilling, and soil transfer (Kiehl et al., 2010), in tropical grasslands, even minor changes in soil structure are likely to hamper natural regeneration from USOs and buried buds. Soil preparation should therefore be used only on 
sites where repeated soil disturbance has already destroyed the belowground bud bank. For example, Sampaio et al. (2015) showed that plowing areas of Cerrado that were previously cultivated or long-served as planted pastures can help reduce invasive species density and increase native species establishment. USOs are extremely difficult to uproot and transfer without damage (Zaloumis, 2013; Le Stradic et al., 2016) and can require long periods of time to develop (Veldman et al., 2015a). Given the importance of bud banks to the regeneration capacity of tropical grasslands (Fidelis et al., 2014; Pausas et al., 2018), determining if and how USOs may be transplanted is a key research need. Among human land uses that severely affect tropical grasslands, surface mining (including open-pit mining) has the most profound local ecological impact (Sonter et al., 2014). As a consequence, in many countries, mining companies are highly encouraged, and often legally obligated, to restore the ecosystems they destroy. Drawing on substantial wealth, some mining companies plan ambitious and expensive restoration projects, including full community translocation (i.e. whole-turf translocation). Ideally, this technique involves removing old-growth grassland turf (i.e. the aboveground plant community and soil to a depth of $c a .40 \mathrm{~cm}$ ), before mining, and then transferring the turf to a nearby site where the plant community and soil has been recently destroyed. At the experimental scale (translocations of $0.04-200 \mathrm{~m}^{2}$ ), such translocations can be successful in grasslands with shallow soils (Le Stradic et al., 2016), but not for grasslands with deeper soils; deeply rooted species and species with large USOs are not amenable to translocation (Fig. 3C, D; Le Stradic et al., 2016). Translocation faces similar limitations as restoration following cultivation: deeply rooted species do not survive translocation (Fig. 3C; Zaloumis, 2013). Despite some success in an experimental context, the financial cost for full community translocation is prohibitively high and turf donor sites are destroyed in the process. Moreover, even if some species survive transplantation, they fail to colonise outside of transplanted plots (Le Stradic, 2012; Zaloumis, 2013). Such poor colonisation may be due to a combination of factors, including unsuitable soil conditions outside the turf plantation area (Kardol, Bezemer \& Van Der Putten, 2009), low seed production, slow growth and recovery after transplant damage to USOs and roots (Fahselt, 2007), and bud dormancy induced by harsh transplant conditions (Le Stradic, 2012; Zaloumis, 2013).

In addition to killing plants that rely on USOs and buried buds, there are a variety of ways that soil-disturbing land uses create conditions that are unsuitable for tropical grassland plant communities. For example, fertilizers (N and $\mathrm{P}$ ) which remain in the soil after cultivation can favour competitive or invasive species (Barbosa et al., 2010; Andrade et al., 2015) and metal content (e.g. copper, cobalt, aluminium) can be changed by mining (Leteinturier et al., 1999; Faucon et al., 2011). Such novel soil conditions may cause restoration plantings to fail, to take a very long time to establish, or to require additional treatments, such as liming (Shutcha et al., 2010) or metal additions [e.g. to elevate copper concentration (Chipeng et al., 2009; Faucon et al., 2012)]. Clearly, some soil amendments, especially those containing expensive elements, cannot be economically applied in all grasslands (Barbosa et al., 2010). Where heavy metal concentrations are too high, Leteinturier et al. (1999, 2001a,b), Shutcha et al. (2010), and Boisson et al. (2015) found that metals can be immobilised via phytostabilisation. Like many other promising restoration experiments, scaling up small plot-level studies of phytostabilisation to landscapes will require additional studies. In temperate grasslands, research has been carried out to try to reduce nutrients $(\mathrm{N}$ and $\mathrm{P})$ in soils in order to favour a high diversity of native species. These N- and P-reduction techniques include: mowing and removing the cut biomass (Maron \& Jefferies, 2001); carbon amendment to reduce $\mathrm{N}$ levels (Wilson \& Gerry, 1995; Reever Morghan \& Seastedt, 1999; Török et al., 2000; Wilson, 2002); and topsoil removal as a restoration technique to reduce both competition from the exotic seed bank and soil N levels (Marrs, 2002; Wilson, 2002; Buisson et al., 2006, 2008). More research on these potential techniques for tropical grassland restoration is needed.

\section{GONGLUSIONS}

(1) Whereas the destruction and degradation of tropical and subtropical old-growth grasslands, including savannas and grassy woodlands, can occur very rapidly, recovery of their biodiverse plant communities occurs slowly, or not at all (Veldman et al., 2015a). Overgrazing, fire exclusion, and woody encroachment can replace tropical old-growth grasslands with low-diversity swards of exotic grasses or dense tree cover in a matter of years to a few decades (e.g. Cava et al., 2018). Grassland conversion for agriculture, plantation forestry, or mining not only destroys plant and animal communities, but also profoundly changes chemical and physical soil features (Brudvig et al., 2013; Le Stradic et al., $2018 a$ ). Our review of the restoration literature suggests that such human-induced environmental change often pushes tropical grasslands across ecological thresholds to alternative ecosystem states, from which recovery, where possible, requires huge efforts and many decades to centuries.

(2) Among key priorities for restoration practice and research, we must determine when state shifts in tropical grasslands qualify as novel ecosystems, from which recovery is ecologically impossible or socially impractical, as opposed to hybrid grasslands, which are amenable to restoration toward the old-growth state (Fig. 3; Hobbs et al., 2009; Hulvey et al., 2013). Given the paucity of tropical grassland restoration research, it is possible that some ecosystem states that we currently perceive to be novel will, after future research and technological innovation, prove capable of recovery towards the old-growth state (Murcia et al., 2014). In the meantime we suggest that recognition of novel ecosystems and their different restoration scope (Fig. 3) can serve to highlight the irreplaceability of tropical old-growth grasslands (Hobbs, Higgs \& Harris, 2014). Because ecological restoration is not 
a panacea for the recovery of tropical grassland biodiversity, in the extensive areas where old-growth grasslands still exist, environmental policies and ecosystem management should prioritise grassland conservation, which must include prescribed fire, wildfire, and/or megafaunal herbivory.

(3) Most tropical old-growth grasslands require frequent endogenous disturbances (i.e. fire and herbivory) to maintain plant diversity and prevent state shifts to low-diversity forests (Fig. 2). Such disturbance-dependent grasslands, common throughout the humid tropics, differ from much rarer edaphic grasslands in key aspects of resilience and restoration (Fig. 3). Of particular note, whereas appropriate livestock management can be used to maintain or restore disturbance-dependent old-growth grasslands, livestock are typically incompatible with the conservation of edaphic old-growth grasslands. Another difference is that disturbance-dependent grasslands, on soils that are favourable to plant growth, are far more susceptible to conversion for agriculture than edaphic grasslands on infertile or poorly drained soils; as such, cultivation represents a far greater threat to disturbance-dependent grasslands (Searchinger et al., 2015) relative to edaphic grasslands. A final notable difference is that because soil conditions in edaphic grasslands severely constrain tree growth, fire exclusion does not result in the same rapid, irreversible state shifts to forest that threaten disturbance-dependent grasslands (Fig. 3A, B; Durigan \& Ratter, 2016). In sum, although disturbance-dependent and edaphic grasslands have many similarities (e.g. herbaceous communities of long-lived perennial plants), recognition of relationships between grassland disturbance regimes and edaphic conditions is critical to anticipating the outcomes of environmental change (Fig. 3A, B) and planning restoration for specific tropical grassland ecosystems (Fig. 3C, D).

(4) Unlike tropical forests, where cessation of humaninduced disturbance is often sufficient for restoration (i.e. passive restoration; Meli et al., 2017), restoration of most tropical grasslands (i.e. disturbance-dependent grasslands; Figs 2 and 3A, C) must include ongoing, active management to maintain endogenous disturbance regimes. Restoration planners, in their consideration of disturbances and degradation in the tropics, should acknowledge that tropical grassland species have evolved for millions of years with endogenous disturbances that do not regularly occur in forests (i.e. fire and grazing; Veldman, 2016); consequently, tropical grassland communities are highly resilient to disturbances that remove aboveground biomass, but not resilient to disturbances that alter soils and destroy underground organs (Bond, 2016; Fig. 3A, B). After repeated soil disturbance or afforestation, tropical grassland restoration is severely limited by the poor colonisation potential (e.g. low seed viability, limited dispersal) of plant species that are characteristic of old-growth grasslands (Veldman et al., 2015a). Further complicating restoration, grassland species that rely on bud banks for persistence are not easily transplanted. Exotic forage grasses, which are commercially available and easy to establish, should never be sown as part of tropical grassland restoration.
(5) Although many of the techniques used to actively restore forests or temperate grasslands are ecologically inappropriate (e.g. fire exclusion; Ratnam et al., 2011) or ineffective when applied to tropical grasslands (e.g. hay or topsoil transfer; Le Stradic et al., 2014a, 2016; Pilon et al., 2018), there are several management tools that do offer hope for ecosystem recovery where degradation is not irreversible (i.e. hybrid grasslands; Fig. 3C, D). Despite this hope, a great deal of confusion still exists over the activities that constitute ecological restoration (Suding et al., 2015), particularly in the context of forest and landscape restoration (Brancalion \& Chazdon, 2017) as applied to tropical savannas and grassland-forest mosaics (Veldman et al., 2015b). Through this review, we have sought to reduce this confusion by offering clarity about the distinct conservation values and ecological attributes of tropical grasslands that require a set of restoration tools that are distinct from the tools applied for forest restoration. To summarise, the tools of tropical grassland restoration include: (1) prescribed fire; (2) appropriate management of livestock and wild herbivores; (3) tree cutting and shrub removal; (4) invasive species control; and (5) reintroduction of native grasses and forbs, via seeding or transplants. Finally, because most tropical old-growth grasslands are dependent on recurring endogenous disturbances, restoration efforts must plan for the long-term maintenance of fire regimes, megafauna herbivory, or both, to prevent woody encroachment from leading to forest expansion.

\section{AGKNOWLEDGMENTS}

This work was supported by the French Embassy / UFMG Chairs 2015 grant and CNRS PICS 2018-2020 [RESIGRASS] grant to E.B. A.F. and G.D. thank GNPq (Conselho Nacional de Desenvolvimento Científico e Tecnológico) for productivity grant (306170/2015-9 and 312292/2016-3, respectively) and FAPESP (Fundação de Amparo à Pesquisa do Estado de São Paulo) for research grant (2015/06743-0, 2014/12337-2). G.E.O. thanks CNPq for a productivity grant (310022/2015-0) and CNPq (grant 477618/2013-8) and Fundação Boticário (grant 0950_20122) for research grants. F.A.O.S. and G.W.F. are supported by CNPq and FAPEMIG. S.T.A. received postdoctoral support from grants \#2014/12728-1 and \#2017/14236-7 from FAPESP, as well as funding from the "Programme de mobilité entrante UAPV". S.L.S. received postdoctoral fellowship \#2016/13232-5 and \#2018/03755-6 from FAPESP. We thank V.M. Temperton and an anonymous reviewer for providing helpful comments to improve an earlier version of this manuscript.

\section{REFERENGES}

References marked with asterisk have been cited within the supporting information

de Abreu, R. C. R., de Assis, G. B., Frison, S., Aguirre, A. \& Durigan, G. (2011). Can native vegetation recover after slash pine cultivation in the Brazilian Savanna? Forest Ecology and Management 262, 1452-1459. 
De Abreu, R. C. R. \& Durigan, G. (2011). Changes in the plant community of a Brazilian grassland savannah after 22 years of invasion by Pinus elliottii Engelm. Plant Ecology \&ं Diversity 4, 269-278.

de Abreu, R. C. R. \& Durigan, G. (2013). Eradicação da invasão por árvores de Pinus no Cerrado. In Manejo Adaptativo: primeiras experiências na Restauração de Ecossistemas (eds G. Durigan and V. Soares Ramos), pp. 43-46. Páginas \& Letras-Editora e Gráfica Ltda, São Paulo.

Abreu, R. C. R., Hoffmann, W. A., Vasconcelos, H. L., Pilon, N. A., Rossatto, D. R. \& Durigan, G. (2017). The biodiversity cost of carbon sequestration in tropical savanna. Science Advances 3, e1701284.

Alvarado, S. T., Buisson, E., Carrière, S. M., Rabarison, H., Rajeriarison, C., Andrianjafy, M., Randriatsivery, F. M., Rasoafaranaivo, M. H., Raharimampionona, J., Lowry, P. P. L. II \& Birkinshaw, C. (2015). Achieving sustainable conservation in Madagascar: the case of the newly established Ibity Mountain Protected Area. Tropical Conservation Science 8, 367-395.

Alvarado, S. T., Buisson, E., Rabarison, H., Birkinshaw, C. \& Lowry, P. P. L. II (2012). Ibity Mountain, Madagascar: background and perspectives for ecological restoration. Ecological Restoration 30, 12-15.

Alvarado, S. T., Buisson, E., Rabarison, H., Rajeriarison, C., Birkinshaw, C. \& Lowry, P. P. L. II (2014). Comparison of plant communities on the Ibity and Itremo massifs, Madagascar, with contrasting conservation histories and current status. Plant Ecology \&0 Diversity 7, 497-508.

Alvarado, S. T., Silva, T. S. F. \& Archibald, S. (2018). Management impacts on fire occurrence: a comparison of fire regimes of African and South American tropical savannas in different protected areas. Fournal of Environmental Management 218, 79-87.

*Ammondt, S. A. \& Litton, C. M. (2012). Competition between native Hawaiian plants and the invasive grass Megathyrsus maximus: implications of functional diversity for ecological restoration. Restoration Ecology 20, 638-646.

Andersen, A. N., Cook, G. D., Corbett, L. K., Douglas, M. M., Eager, R. W., Russell-Smith, J., Setterfield, S. A., Williams, R. J. \& Woinarski, J. C. Z. (2005). Fire frequency and biodiversity conservation in Australian tropical savannas: implications from the Kapalga fire experiment. Austral Ecology 30, 155-167.

Andrade, B. O., Косh, C., Boldrini, I. I., Vélez-Martin, E., Hasenack, H., Hermann, J.-M., Kollmann, J., Pillar, V. D. \& Overbeck, G. E. (2015). Grassland degradation and restoration: a conceptual framework of stages and thresholds illustrated by southern Brazilian grasslands. Natureza \&̊ Conservação 13, 95-104.

*Ansley, R. J. \& Castellano, M. J. (2006). Strategies for savanna restoration in the Southern Great Plains: effects of fire and herbicides. Restoration Ecology 14, 420-428. Appezzato-da-Glória, B., Hayashi, A. H. H., Cury, G., Soares, M. K. M. K. M. \& Rocha, R. (2008). Underground systems of Asteraceae species from the Brazilian Cerrado. The Journal of the Torrey Botanical Society 135, 103-113.

*Aronson, J., Floret, G., Le Floc'h, E., Ovalle, G. \& Pontanier, R. (1993). Restoration and rehabilitation of degraded ecosystems in arid and semi-arid lands. II. Case studies in Southern Tunisia, Central Chile and Northern Cameroon. Restoration Ecology 1, 168-187.

Aronson, M. F. J. (2013). Status and challenges of grassland restoration in the United States. Ecological Restoration 31, 119-119.

Aschenbach, T. A., Foster, B. L. \& Imm, D. W. (2010). The initial phase of a longleaf pine-wiregrass savanna restoration: species establishment and community responses. Restoration Ecology 18, 762-771.

DE Assis, G. B. (2017). Invasão do campo cerrado por braquiária (Urochloa decumbens): perdas de diversidade e técnicas de restauração. $\mathrm{PhD}$ Thesis: Jardim Botânico do Rio de Janeiro \& Escola Nacional de Botânica Tropical, Rio de Janeiro.

Bach, E. M., Baer, S. G., Meyer, C. K. \& Six, J. (2010). Soil texture affects soil microbial and structural recovery during grassland restoration. Soil Biology and Biochemistry 42, 2182-2191.

Barbosa, N. P. U., Fernandes, G. W., Carneiro, M. A. A. \& Júnior, L. A. C. (2010). Distribution of non-native invasive species and soil properties in proximity to paved roads and unpaved roads in a quartzitic mountainous grassland of southeastern Brazil (rupestrian fields). Biological Invasions 12, 3745-3755.

Batista, E. K. L., Russell-Smith, J., França, H. \& Figueira, J. E. C. (2018). An evaluation of contemporary savanna fire regimes in the Canastra National Park, Brazil: outcomes of fire suppression policies. Fournal of Environmental Management 205, 40-49.

Beckage, B. \& Stout, I. J. (2000). Effects of repeated burning on species richness in a Florida pine savanna: a test of the intermediate disturbance hypothesis. Fournal of Vegetation Science 11, 113-122.

te Beest, M., Cromsigt, J. P. G. M., Ngobese, J. \& Olff, H. (2012). Managing invasions at the cost of native habitat? An experimental test of the impact of fire on the invasion of Chromolaena odorata in a South African savanna. Biological Invasions 14, 607-618.

BELYEA, L. R. (2004). Beyond ecological filters: feedback networks in the assembly and restoration of community structure. In Assembly Rules and Restoration Ecology: Bridging the Gap Between Theory and Practice (eds V. M. Temperton, R. J. Hobbs, T. Nuttle and S. Halle), pp. 115-131. Island Press, Washington.
Blanco, C., Sosinski, E., Santos, B., Silva, M. \& Pillar, V. (2007). On the overlap between effect and response plant functional types linked to grazing. Community Ecology 8, 57-65.

Boisson, S., Stradic, S. L., Collignon, J., Séleck, M., Malaisse, F., Shutcha, M. N., Faucon, M.-P. \& Mahy, G. (2015). Potential of copper-tolerant grasses to implement phytostabilisation strategies on polluted soils in South D. R. Congo. Environmental Science and Pollution Research 23, 1-13.

Boldrini, I. I. \& EGGERs, L. (1996). Vegetação campestre do sul do Brasil: dinâmica de espécies à exclusão do gado. Acta Botanica Brasilica 10, 37-50.

Bond, W. J. (2016). Ancient grasslands at risk. Science 351, 120-122.

Bond, W. J. \& KeEley, J. E. (2005). Fire as a global 'herbivore': the ecology and evolution of flammable ecosystems. Trends in Ecology E Evolution 20, 387-394.

Bond, W. J. \& Midgley, J. J. (2001). Ecology of sprouting in woody plants: the persistence niche. Trends in Ecology \& Evolution 16, 45-51.

Bond, W. J. \& Midgley, G. F. (2012). Carbon dioxide and the uneasy interactions of trees and savannah grasses. Philosophical Transactions of the Royal Society B: Biological Sciences 367, 601-612.

Bond, W. J. \& PARr, C. L. (2010). Beyond the forest edge: ecology, diversity and conservation of the grassy biomes. Biological Conservation 143, 2395-2404.

Bond, W. J., Woodward, F. I. \& Midgley, G. F. (2005). The global distribution of ecosystems in a world without fire. New Phytologist 165, 525-538.

Bond, W. \& Zaloumis, N. P. (2016). The deforestation story: testing for anthropogenic origins of Africa's flammable grassy biomes. Philosophical Transactions Royal Society B: Biological Sciences 371, 20150170.

Booysen, P. de. V. \& Tainton, N. M. (1984). Ecological Effects of Fire in South African Ecosystems. Springer-Verlag, Berlin, Heidelberg, New York, Tokyo.

*Bowman, D. M. J. S. \& LegGe, S. (2016). Pyrodiversity - why managing fire in food webs is relevant to restoration ecology. Restoration Ecology 24, 848-853.

*Brady, C. J. \& Noske, R. A. (2010). Succession in bird and plant communities over a 24-year chronosequence of mine rehabilitation in the Australian monsoon tropics. Restoration Ecology 18, 855-864.

Brancalion, P. H. S. \& Chazdon, R. L. (2017). Beyond hectares: four principles to guide reforestation in the context of tropical forest and landscape restoration. Restoration Ecology 25, 491-496.

*Brewer, J. S. (2005). The lack of favorable responses of an endangered pitcher plant to habitat restoration. Restoration Ecology 13, 710-717.

Brewer, J. S., Cunningham, A. L., Moore, T. P., Brooks, R. M. \& Waldrup, J. L. (2009). A six-year study of fire-related flowering cues and coexistence of two perennial grasses in a wet longleaf pine (Pinus palustris) savanna. Plant Ecology 200, $141-154$.

Brewer, J. S. \& Platt, W. J. (1994a). Effects of fire season and herbivory on reproductive success in a clonal forb, Pityopsis graminifolia. Fournal of Ecology 82, $665-675$.

Brewer, J. S. \& Platt, W. J. (1994b). Effects of fire season and soil fertility on clonal growth in a pyrophilic forb, Pityopsis graminifolia (Asteraceae). American fournal of Botany 81, 805-814.

Briske, D. D., Bestelmeyer, B. T., Stringham, T. K. \& Shaver, P. L. (2008), Recommendations for development of resilience-based state-and-transition models. Rangeland Ecology \& Management 61, 359-367.

Brooks, K. J., Setterfield, S. A. \& Douglas, M. M. (2010). Exotic grass invasions: applying a conceptual framework to the dynamics of degradation and restoration in Australia's tropical savannas. Restoration Ecology 18, 188-197.

Brudvig, L. A., Grman, E., Habeck, G. W., Orrock, J. L. \& Ledvina, J. A. (2013). Strong legacy of agricultural land use on soils and understory plant communities in longleaf pine woodlands. Forest Ecology and Management 310, 944-955.

Brudvig, L. A., Orrock, J. L., Damschen, E. I., Collins, C. D., Hahn, P. G. Mattingly, W. B., Veldman, J. W. \& Walker, J. L. (2014). Land-use history and contemporary management inform an ecological reference model for Longleaf Pine woodland understory plant communities. PLoS One 9, e86604.

Buisson, E., Anderson, S., Holl, K. D., Corcket, E., Hayes, G. F., Peeters, A. \& Dutoit, T. (2008). Reintroduction of Nassella pulchra to California coastal grasslands: effects of topsoil removal, plant neighbour removal and grazing. Applied Vegetation Science 11, 195-204.

Buisson, E., Holl, K. D., Anderson, S., Corcket, E., Hayes, G. F., Torre, F., Peteers, A. \& Dutoit, T. (2006). Effect of seed source, topsoil removal, and plant neighbor removal on restoring California coastal prairies. Restoration Ecology 14, 569-577.

Butler, O. M., Elser, J. J., Lewis, T., Mackey, B. \& Chen, C. (2018). The phosphorus-rich signature of fire in the soil-plant system: a global meta-analysis. Ecology Letters 21, 335-344.

Carvalho, F. M. V., De Marco, P. J. \& Ferreira, L. G. (2009). The Cerrado into-pieces: habitat fragmentation as a function of landscape use in the savannas of Central Brazil. Biological Conservation 142, 1392-1403.

Case, M. F. \& Staver, A. C. (2016). Fire prevents woody encroachment only at higher-than-historical frequencies in a south African savanna. Fournal of Applied Ecology 54, 955-962.

Castillioni, K. P. (2015). Avaliação de diferentes técnicas de manejo para o controle de gramíneas invasoras em unidade de conservação de Cerrado. MSc thesis: UNESP, Rio Claro. 
Cava, M. G. B., Pilon, N. A. L., Ribeiro, M. C. \& Durigan, G. (2018). Abandoned pastures cannot spontaneously recover the attributes of old-growth savannas. Fournal of Applied Ecology 55, 1164-1172.

*Channan, S., Collins, K. \& Emanuel, W. R. (2014). Global Mosaics of the Standard MODIS Land Cover Type Data. University of Maryland and the Pacific Northwest National Laboratory, College Park.

Chazdon, R. L., Brancalion, P. H. S., Lamb, D., Laestadius, L., Calmon, M. \& Kumar, C. (2017). A policy-driven knowledge agenda for global forest and landscape restoration. Conservation Letters 10, 125-132.

Chipeng, F. K., Hermans, C., Colinet, G., Faucon, M.-P., Ngongo, M., Meerts, P. \& Verbruggen, N. (2009). Copper tolerance in the cuprophyte Haumaniastrum katangense (S. Moore) P.A. Duvign. \& Plancke. Plant and Soil 328, $235-244$.

Cingolani, A. M., Noy-Meir, I. \& Díaz, S. (2005). Grazing effects on rangeland diversity: a synthesis of contemporary models. Ecological Applications 15, 757-773.

Clarke, P. J., Lawes, M. J., Midgley, J.J., Lamont, B. B., OJeda, F., Burrows, G. E., Enright, N. J. \& Knox, K. J. E. (2013). Resprouting as a key functional trait: how buds, protection and resources drive persistence after fire. New Phytologist 197, 19-35.

Coelho, M. S., de Siqueira Neves, F., Perillo, L. N., Morellato, L. P. C. \& FERNANDES, G. W. (2018). Forest archipelagos: a natural model of metacommunity under the threat of fire. Flora 238, 244-249.

*Cohen, S., Braham, R. \& Sanchez, F. (2004). Seed bank viability in disturbed longleaf pine sites. Restoration Ecology 12, 503-515.

Collatz, G. J., Berry, J. A. \& Clark, J. S. (1998). Effects of climate and atmospheric CO2 partial pressure on the global distribution of C4 grasses: present, past, and future. Oecologia 114, 441-454.

Conceição, A. A., Alencar, T. G., Souza, J. M., Moura, A. D. C. \& Silva, G. A. (2013). Massive post-fire flowering events in a tropical mountain region of Brazil: high episodic supply of floral resources. Acta Botanica Brasilica 27, 847-850.

*Condon, B. \& Putz, F. E. (2007). Countering the broadleaf invasion: financial and carbon consequences of removing hardwoods during longleaf pine savanna restoration. Restoration Ecology 15, 296-303.

Cordero, R. L., Torchelsen, F. P., Overbeck, G. E. \& Anand, M. (2016). Invasive gorse (Ulex europaeus, Fabaceae) changes plant community structure in subtropical forest-grassland mosaics of southern Brazil. Biological Invasions 18, 1629-1643.

*Costa, C. B., Ribeiro, S. P. \& Castro, P. T. A. (2010). Ants as bioindicators of natural succession in savanna and riparian vegetation impacted by dredging in the Jequitinhonha River basin, Brazil. Restoration Ecology 18, 148-157.

Coutinho, L. M. (1990). Fire in the ecology of the Brazilian Cerrado. In Fire in the Tropical Biota (ed J. G. Goldammer), pp. 82-105. Springer, Berlin, Heidelberg.

Crowley, G. M. \& Garnett, S. T. (1998). Vegetation change in the grasslands and grassy woodlands of east-central Cape York Peninsula, Australia. Pacific Conservation Biology 4, 132-148.

Daibes, L. F., Zupo, T., Silveira, F. A. O. \& Fidelis, A. (2017). A field perspective on effects of fire and temperature fluctuation on Cerrado legume seeds. Seed Science Research 27, 74-83.

Damasceno, G., Souza, L., Pivello, V. R., Gorgone-Barbosa, E., Giroldo, P. Z. \& Fidelis, A. (in press). Impact of invasive grasses on Cerrado under natural regeneration. Biological Invasions. https://doi.org/10.1007/s10530-018-1800-6, in press.

Dantas, V. de. L., Hirota, M., Oliveira, R. S. \& Pausas, J. G. (2016). Disturbance maintains alternative biome states. Ecology Letters 19, 12-19.

Dantas, V. de. L. \& Pausas, J. G. (2013). The lanky and the corky: fire-escape strategies in savanna woody species. Fournal of Ecology 101, 1265-1272.

Dayamba, S. D., Savadogo, P., Sawadogo, L., Tiveau, D., Zida, D., Tigabu, M. \& Oden, P. C. (2010). Community dynamics and phytomass of herbaceous species in the Sudaniansavanna-woodlands of Burkina Faso: short-term impact of burning season. African Fournal of Range \& Forage Science 27, 171-177.

Dayamba, S. D., Tigabu, M., Sawadogo, L. \& Oden, P. C. (2008). Seed germination of herbaceous and woody species of the Sudanian savanna-woodland in response to heat shock and smoke. Forest Ecology and Management 256, 462-470.

Dayrell, R. L. C., Arruda, A. J., Buisson, E. \& Silveira, F. A. O. (2016). Overcoming challenges on using native seeds for restoration of megadiverse resource-poor environments: a reply to Madsen et al. Restoration Ecology 24, 710-713.

Dayrell, R. L. C., Garcia, Q. S., Negreiros, D., Baskin, C. C., Baskin, J. M. \& Silveira, F. A. O. (2017). Phylogeny strongly drives seed dormancy and quality in a climatically buffered hotspot for plant endemism. Annals of Botany 119, 267-277.

Delhaye, G., Violle, G., Séleck, M., Ilunga wa Ilunga, E., Daubie, I., Mahy, G. \& Meerts, P. (2016). Community variation in plant traits along copper and cobalt gradients. Fournal of Vegetation Science 27, 854-864.

*Dimiceli, C. M., Carroll, M. L., Sohlberg, R. A., Huang, G., Hansen, M. C. \& Townshend, J. R. G. (2011). Annual Global Automated MODIS Vegetation Continuous Fields (MOD44B) at $250 \mathrm{~m}$ Spatial Resolution for Data Years Beginning Day 65, 2000-2010, Collection 5 Percent Tree Cover. University of Maryland, College Park. Available at http://glcf.umd.edu/data/vcf/ [accessed 11 September 2018].
Dixon, A. P., Faber-Langendoen, D., Josse, C., Morrison, J. \& Loucks, C. J. (2014). Distribution mapping of world grassland types. Fournal of Biogeography 41, 2003-2019.

Drewa, P. B., Platt, W. J. \& Moser, E. B. (2002). Fire effects on resprouting of shrubs in headwaters of southeastern longleaf pine savannas. Ecology 83, 755-767.

Dresseno, A. L. P., Guido, A., Balogianni, V. \& Overbeck, G. E. (in press). Negative effects of an invasive grass, but not of native grasses, on plant species richness along a cover gradient. Austral Ecology. https://doi.org/10.1111/aec.12644, in press.

Driscoll, D. A., Lindenmayer, D. B., Bennett, A. F., Bode, M., Bradstock, R. A., Cary, G. J., Clarke, M. F., Dexter, N., Fensham, R., Friend, G., Gill, M., James, S., Kay, G., Keith, D. A., MacGregor, C., et al. (2010). Fire management for biodiversity conservation: key research questions and our capacity to answer them. Biological Conservation 143, 1928-1939.

Durigan, G. \& RatTer, J. A. (2016). The need for a consistent fire policy for Cerrado conservation. Fournal of Applied Ecology 53, 11-15.

Duvigneaud, P. \& Denaeyer-De Smet, S. (1963). Cuivre et végétation du Katanga. Bulletin de la Société Royale de Botanique de Belgique / Bulletin van de Koninklijke Belgische Botanische Vereniging 96, 93-231.

*Ellsworth, L. M., Litton, C. M. \& Leary, J. J. K. (2015). Restoration impacts on fuels and fire potential in a dryland tropical ecosystem dominated by the invasive grass Megathyrsus maximus. Restoration Ecology 23, 955-963.

FAHSELT, D. (2007). Is transplanting an effective means of preserving vegetation? Canadian Fournal of Botany 85, 1007-1017.

Faucon, M.-P., Chipeng, F., Verbruggen, N., Mahy, G., Colinet, G., Shutcha, M., Pourret, O. \& Meerts, P. (2012). Copper tolerance and accumulation in two cuprophytes of south Central Africa: Crepidorhopalon perennis and C. tenuis (Linderniaceae). Environmental and Experimental Botany 84, 11-16.

Faucon, M.-P., Le Stradic, S., Boisson, S., Wa Ilunga, E. I., Séleck, M., Lange, B., Guillaume, D., Shutcha, M. N., Pourret, O., Meerts, P. \& Mahy, G. (2016). Implication of plant-soil relationships for conservation and restoration of copper-cobalt ecosystems. Plant and Soil 403, 153-165.

Faucon, M.-P., Parmentier, I., Colinet, G., Mahy, G., Ngongo Luhembwe, M. \& Meerts, P. (2011). May rare metallophytes benefit from disturbed soils following mining activity? The case of Crepidorhopalon tenuis in Katanga (D. R. Congo). Restoration Ecology 19, 333-343.

Fedrigo, J. K., Ataide, P. F., Filho, J. A., Oliveira, L. V., Jaurena, M., Laca, E. A., Overbeck, G. E. \& Nabinger, C. (2018). Temporary grazing exclusion promotes rapid recovery of species richness and productivity in a long-term overgrazed Campos grassland. Restoration Ecology 28, 677-685.

Fensham, R. J. (1998). The grassy vegetation of the Darling Downs, south-eastern Queensland, Australia. Floristics and grazing effects. Biological Conservation 84, $301-310$.

Fensham, R. J., Butler, D. W., Fairfax, R. J., Quintin, A. R. \& Dwyer, J. M. (2016). Passive restoration of subtropical grassland after abandonment of cultivation. Fournal of Applied Ecology 53, 274-283.

Fernandes, G. W. (2016). Ecology and Conservation of Mountain-Top Grasslands in Brazil. Springer International Publishing, Cham, Switzerland.

*Ferreira, M. C., Walter, B. M. T. \& Vieira, D. L. M. (2015). Topsoil translocation for Brazilian savanna restoration: propagation of herbs, shrubs, and trees. Restoration Ecology 23, 723-728.

Fichino, B. S., Fidelis, A., Schmidt, I. \& Pivello, V. (2012). Efeitos de altas temperaturas na germinação de sementes de capim-dourado (Syngonanthus nitens (Bong.) Ruhland, Eriocaulaceae): implicações para o manejo. Acta Botanica Brasilica 26, 508-511.

Fichino, B. S., Dombroski, J. R. G., Pivello, V. R. \& Fidelis, A. (2016). Does fire trigger seed germination in the Neotropical Savannas? Experimental tests with six Cerrado species. Biotropica 48, 181-187.

Fidelis, A., Appezzato-da-Glória, B., Pillar, V. D. \& Pfadenhauer, J. (2014). Does disturbance affect bud bank size and belowground structures diversity in Brazilian subtropical grasslands? Flora 209, 110-116.

Fidelis, A. \& Blanco, C. (2014). Does fire induce flowering in Brazilian subtropical grasslands? Applied Vegetation Science 17, 690-699.

Fidelis, A., Blanco, C. C., Müller, S. C., Pillar, V. D. \& Pfadenhauer, J. (2012). Short-term changes caused by fire and mowing in Brazilian Campos grasslands with different long-term fire histories. Fournal of Vegetation Science 23, $552-562$.

Fidelis, A., Daibes, L. F. \& Martins, A. R. (2016). To resist or to germinate? The effect of fire on legume seeds in Brazilian subtropical grasslands. Acta Botanica Brasilica 30, 147-151.

Fidelis, A., Lyra, M. F.di. S. \& Pivello, V. R. (2013). Above- and below-ground biomass and carbon dynamics in Brazilian Cerrado wet grasslands. Fournal of Vegetation Science 24, 356-364.

Fill, J. M., Platt, W. J., Welch, S. M., Waldron, J. L. \& Mousseau, T. A. (2015). Updating models for restoration and management of fiery ecosystems. Forest Ecology and Management 356, 54-63. 
Freudenberger, D. \& Gibson-Roy, P. (2011). Restoration as a learning process lessons from temperate grasslands. Australasian Plant Conservation: Journal of the Australian Network for Plant Conservation 20, 4-6.

*Friedl, M. A., Sulla-Menashe, D., Tan, B., Schneider, A., Ramankutty, N., Sibley, A. \& HuANG, X. (2010). MODIS collection 5 global land cover: algorithm refinements and characterization of new datasets. Remote Sensing of Environment 114, $168-182$.

Frost, C. C. (1993). Four centuries of changing landscape patterns in the longleaf pine ecosystem. In Proceedings of the Tall Timbers Fire Ecology Conference, Tallahassee, FL, USA, pp. 17-43.

Fuhlendorf, S. D. \& Engle, D. M. (2001). Restoring heterogeneity on rangelands: ecosystem management based on evolutionary grazing patterns. Bioscience 51, $625-632$

Fuhlendorf, S. D., Engle, D. M., Kerby, J. \& Hamilton, R. (2009). Pyric herbivory: rewilding landscapes through the recoupling of fire and grazing. Conservation Biology 23, 588-598.

*Funk, C., Peterson, P., Landsfeld, M., Pedreros, D., Verdin, J., Shukla, S., Husak, G., Rowland, J., Harrison, L., Hoell, A. \& Michaelsen, J. (2015). The climate hazards infrared precipitation with stations - a new environmental record for monitoring extremes. Scientific Data 2, 150066.

Fynn, R. W. S., Augustine, D. J., Peel, M. J. S. \& De Garine-Wichatitsky, M. (2016). Strategic management of livestock to improve biodiversity conservation in African savannahs: a conceptual basis for wildlife-livestock coexistence. Fournal of Applied Ecology 53, 388-397.

*Gewex Islscp Project (2007). ISLSCP - I, volume 1: vegetation data. NCAS British Atmospheric Data Centre, Date of Citation. Available at: http://catalogue.ceda.ac .uk/uuid/5a226b1468ca4fc lace5e76815a la4de [accessed 11 September 2018].

Ghebrehiwot, H. M., Kulkarni, M. G., Kirkman, K. P. \& Van Staden, J. (2009). Smoke solutions and temperature influence the germination and seedling growth of South African mesic grassland species. Rangeland Ecology \& Management 62, 572-578.

Gibson, D. J. (2009). Grasses and Grassland Ecology. Oxford University Press, Oxford, UK.

Gomes, V. M., Negreiros, D., Fernandes, G. W., Pires, A. C. V., Silva, A. C. D. R. \& Le Stradic, S. (2018). Long-term monitoring of shrub species translocation in degraded Neotropical mountain grassland. Restoration Ecology 26, $91-96$.

Goncalves, J. L. de. M., Alvares, G. A., Higa, A. R., Silva, L. D., Alfenas, A. C., Stahl, J., Ferraz, S. F. de. B., Lima, W. de. P., Brancalion, P. H. S., Hubner, A., Bouillet, J.-P. D., Laclau, J.-P., Nouvellon, Y. \& Epron, D. (2013). Integrating genetic and silvicultural strategies to minimize abiotic and biotic constraints in Brazilian eucalypt plantations. Forest Ecology \& Management 301, 6-27.

Gorgone-BARbosa, E. (2016). A relação entre fogo e uma gramínea invasora no Cerrado: o fogo pode ser utilizado como uma estratégia de controle? PhD, UNESP, Rio Claro, Brazil.

Gorgone-Barbosa, E., Pivello, V. R., Baeza, M. J. \& Fidelis, A. (2016a). Disturbance as a factor in breaking dormancy and enhancing invasiveness of African grasses in a Neotropical Savanna. Acta Botanica Brasilica 30, 131-137.

Gorgone-Barbosa, E., Pivello, V. R., Rissi, M. N., Zupo, T., Rissi, M. N. \& Fidelis, A. (2016b). A importância da consideração de espécies invasoras no manejo integrado do fogo. Biodiversidade Brasileira 6, 27-40.

Gorgone-Barbosa, E., Pivello, V. R., Bautista, S., Zupo, T., Rissi, M. N. \& Fidelis, A. (2015). How can an invasive grass affect fire behavior in a tropical savanna? A community and individual plant level approach. Biological Invasions 17, $423-431$

GPFLR (2016). Global partnership on forest and landscape restoration. Available at http://www.forestlandscaperestoration.org/. Accessed 23.02.2018.

Grime, J. P., Brown, V. K., Thompson, K., Masters, G. J., Hillier, S. H., Clarke, I. P., Askew, A. P., Corker, D. \& Kielty, J. P. (2000). The response of two contrasting limestone grasslands to simulated climate change. Science $\mathbf{2 8 9}$, $762-765$

Harrington, T. B. (2011). Overstory and understory relationships in longleaf pine plantations 14 years after thinning and woody control. Canadian foumal of Forest Research 41, 2301-2314.

Hempson, G. P., Archibald, S. \& Bond, W. J. (2015). A continent-wide assessment of the form and intensity of large mammal herbivory in Africa. Science 350, 1056-1061.

Hempson, G. P., Archibald, S. \& Bond, W.J. (2017). The consequences of replacing wildlife with livestock in Africa. Scientific Reports 7, 17196.

Hiers, J. K., O’Brien, J. J., Will, R. E. \& Mitchell, R. J. (2007). Forest floor depth mediates understory vigor in xeric Pinus palustris ecosystems. Ecological Applications 17, 806-814.

Hirota, M., Holmgren, M., Nes, E. H. V. \& Scheffer, M. (2011). Global resilience of tropical forest and savanna to critical transitions. Science 334, 232-235.

Hirst, R. A., Pywell, R. F., Marrs, R. H. \& Putwain, P. D. (2003). The resistance of a chalk grassland to disturbance. Fournal of Applied Ecology 40, 368-379.

Hobbs, R. J., Higgs, E. \& Harris, J. A. (2009). Novel ecosystems: implications for conservation and restoration. Trends in Ecology \& Evolution 24, 599-605.

Hobbs, R. J., Higgs, E. S. \& Harris, J. A. (2014). Novel ecosystems: concept or inconvenient reality? A response to Murcia et al. Trends in Ecology \& Evolution 29, $645-646$
Hobbs, R. J., Jentsch, A. \& Temperton, V. M. (2007). Restoration as a process of assembly and succession mediated by disturbance. In Linking Restoration and Ecological Succession (eds L. R. Walker, J. Walker and R. J. Новbs), pp. 150-167. Springer-Verlag, New York, USA.

Hobbs, R. J. \& Norton, D. A. (1996). Towards a conceptual framework for restoration ecology. Restoration Ecology 4, 93-110.

Новвs, R. J. \& Suding, K. N. (2013). New Models for Ecosystem Dynamics and Restoration. Island Press, Washington, Covelo, London.

Hodgson, D., McDonald, J. L. \& Hosken, D. J. (2015). What do you mean, 'resilient'? Trends in Ecology \&̊ Evolution 30, 503-506.

Hoffmann, W. A. (1996). The effects of fire and cover on seedling establishment in a Neotropical Savanna. Fournal of Ecology 84, 383-393.

Hoffmann, W. A. (1998). Post-burn reproduction of woody plants in a neotropical savanna: the relative importance of sexual and vegetative reproduction. Fournal of Applied Ecology 35, 422-433.

Hoffmann, W. A., Geiger, E. L., Gotsch, S. G., Rossatto, D. R., Silva, L. C. R., Lau, O. L., Haridasan, M. \& Franco, A. C. (2012). Ecological thresholds at the savanna-forest boundary: how plant traits, resources and fire govern the distribution of tropical biomes. Ecology Letters 15, 759-768.

Hoffmann, W. A. \& Haridasan, M. (2008). The invasive grass, Melinis minutiflora, inhibits tree regeneration in a Neotropical savanna. Austral Ecology 33, 29-36.

*Hopcraft, J. G. C. (2015). Elephants and savanna woodland ecosystems: a study from Chobe National Park, Botswana. Restoration Ecology 23, 964-965.

Hulvey, K. B., Standish, R. J., Hallet, L. M., Starzomski, B. M., Murphy, S. D., Nelson, G. R., Gardener, M. R., Kennedy, P. L., Seastedt, T. R. \& Suding, K. N. (2013). Incorporating novel ecosystems into management frameworks. In Novel Ecosystems: Intervening in the New Ecological World Order (eds R. J. Hobbs, E. S. Higgs and C. Hall), pp. 157-171. Wiley-Blackwell, Chichester.

Ilunga wa Ilunga, E., Mahy, G., Piqueray, J., Séleck, M., Shutcha, M. N., Meerts, P. \& Faucon, M.-P. (2015). Plant functional traits as a promising tool for the ecological restoration of degraded tropical metal-rich habitats and revegetation of metal-rich bare soils: a case study in copper vegetation of Katanga, DRC. Ecological Engineering 82, 214-221.

Jentsch, A., Kreyling, J., Elmer, M., Gellesch, E., Glaser, B., Grant, K., Hein, R., Lara, M., Mirzae, H., Nadler, S. E., Nagy, L., Otieno, D., Pritsch, K., Rascher, U., Schädler, M., et al. (2011). Climate extremes initiate ecosystem-regulating functions while maintaining productivity. Fournal of Ecology $\mathbf{9 9}$, $689-702$.

Jordan, W. R. (2005). The Tallgrass Restoration Handbook: For Prairies, Savannas, and Woodlands. Island Press, Washington, D.C. / Covelo, California.

Joshi, A. A., Sankaran, M. \& Ratnam, J. (2018). 'Foresting' the grassland: historical management legacies in forest-grassland mosaics in southern India, and lessons for the conservation of tropical grassy biomes. Biological Conservation 224, 144-152.

Joubert, L., Pryke, J. S. \& Samways, M. J. (2017). Moderate grazing sustains plant diversity in Afromontane grassland. Applied Vegetation Science 20, 340-351.

Kane, J. M., Varner, J. M. \& Hiers, J. K. (2008). The burning characteristics of southeastern oaks: discriminating fire facilitators from fire impeders. Forest Ecology and Management 256, 2039-2045.

Kardol, P., Bezemer, T. M. \& Van Der Putten, W. H. (2009). Soil organism and plant introductions in restoration of species-rich grassland communities. Restoration Ecology 17, 258-269.

KeEley, J. E. \& Fotheringham, C. J. (2000). Role of fire in regeneration from seed. In Seeds: The Ecology of Regeneration in Plant Communities, 2nd Edition (ed. M. FENNER), pp. 311-330. CAB International, Wallingford.

Kiehl, K., Kirmer, A., Donath, T. W., Rasran, L. \& Hölzel, N. (2010). Species introduction in restoration projects - evaluation of different techniques for the establishment of semi-natural grasslands in Central and Northwestern Europe. Basic and Applied Ecology 11, 285-299.

Kirkman, L. K., Coffey, K. L., Mitchell, R. J. \& Moser, E. B. (2004). Ground cover recovery patterns and life-history traits: implications for restoration obstacles and opportunities in a species-rich savanna. Fournal of Ecology 92, 409-421.

Koch, C., Conradi, T., Gossner, M. M., Hermann, J.-M., Leidinger, J., Meyer, S. T., Overbeck, G. E., Weisser, W. W. \& Kollmann, J. (2016). Management intensity and temporary conversion to other land-use types affect plant diversity and species composition of subtropical grasslands in southern Brazil. Applied Vegetation Science 19, 589-599.

Kolb, R. M., Pilon, N. A. L., Durigan, G., Kolb, R. M., Pilon, N. A. L. \& Durigan, G. (2016). Factors influencing seed germination in Cerrado grasses. Acta Botanica Brasilica 30, 87-92.

KolbeK, J. \& Alves, R. J. V. (2008). Impacts of cattle, fire and wind in rocky savannas, Southeastern Brazil. Acta Universitatis Carolinae 22, 111-130.

Kreye, J. K., Varner, J. M., Hiers, J. K. \& Mola, J. (2013). Toward a mechanism for eastern North American forest mesophication: differential litter drying across 17 species. Ecological Applications 23, 1976-1986.

*Ladouceur, E. \& Mayfield, M. M. (2017). The early response of subtropical tussock grasslands to restoration treatments. Restoration Ecology 25, 689-695. 
*LaI, P. C. C. \& Wong, B. S. F. (2005). Effects of tree guards and weed mats on the establishment of native tree seedlings: implications for forest restoration in Hong Kong, China. Restoration Ecology 13, 138-143.

LAmont, B. B. \& Downes, K. S. (2011). Fire-stimulated flowering among resprouters and geophytes in Australia and South Africa. Plant Ecology 212, 2111-2125.

LAmont, B. B. \& Wiens, D. (2003). Are seed set and speciation rates always low among species that resprout after fire, and why? Evolutionary Ecology 17, 277-292.

Langan, L., Higgins, S. I. \& Scheiter, S. (2017). Climate-biomes, pedo-biomes or pyro-biomes: which world view explains the tropical forest-savanna boundary in South America? Journal of Biogeography 44, 2319-2330.

Lark, T. J., Salmon, J. M. \& Gibbs, H. K. (2015). Cropland expansion outpaces agricultural and biofuel policies in the United States. Environmental Research Letters 10, 044003.

Laurance, W. F., Dell, B., Turton, S. M., Lawes, M. J., Hutley, L. B., McCallum, H., Dale, P., Bird, M., Hardy, G., Prideaux, G., Gawne, B., McMahon, C. R., Yu, R., Hero, J.-M., Schwarzkopf, L., et al. (2011). The 10 Australian ecosystems most vulnerable to tipping points. Biological Conservation 144 $1472-1480$.

Le Stradic, S. (2012). Composition, phenology and restoration of campo rupestre mountain grasslands - Brazil. PhD Thesis: Universidade Federal de Minas Gerais, Brazil \& Université d'Avignon et des Pays de Vaucluse, France.

Le Stradic, S., Buisson, E. \& Fernandes, G. W. (2014a). Restoration of Neotropical grasslands degraded by quarrying using hay transfer. Applied Vegetation Science 17, $482-492$.

Le Stradic, S., Buisson, E., Negreiros, D., Campagne, P. \& Wilson FERnANDES, G. (2014b). The role of native woody species in the restoration of Campos Rupestres in quarries. Applied Vegetation Science 17, 109-120.

Le Stradic, S., Fernandes, G. W. \& Buisson, E. (2018a). No recovery of old-growth campo rupestre grasslands after quarrying: implications for conservation and restoration. Restoration Ecology 26, S151-S159.

Le Stradic, S., Hernandez, P., Fernandes, G. W. \& Buisson, E. (2018b). Regeneration after fire in campo rupestre grassland: short and long term vegetation dynamics. Flora 238, 191-200.

Le Stradic, S., Séleck, M., Lebrun, J., Boisson, S., Handjila, G., Faucon, M.-P., ENK, T. \& Mahy, G. (2016). Comparison of translocation methods to conserve metallophyte communities in the Southeastern D.R. Congo. Environmental Science and Pollution Research 23, 13681-13692.

Le Stradic, S., Silveira, F. A. O., Buisson, E., Cazelles, K., Carvalho, V. \& FERnANDES, G. W. (2015). Diversity of germination strategies and seed dormancy in herbaceous species of campo rupestre grasslands. Austral Ecology 40, 537-546.

Lehmann, C. E. R., Anderson, T. M., Sankaran, M., Higgins, S. I., Archibald, S., Hoffmann, W. A., Hanan, N. P., Williams, R. J., Fensham, R. J., Felfili, J., Hutley, L. B., Ratnam, J., Jose, J. S., Montes, R., Franklin, D., et al. (2014). Savanna vegetation-fire-climate relationships differ among continents. Science $343,548-552$.

Lehmann, C. E. R., Archibald, S. A., Hoffmann, W. A. \& Bond, W. J. (2011). Deciphering the distribution of the savanna biome. New Phytologist 191, 197-209.

Lehmann, C. E. R. \& PARR, C. L. (2016). Tropical grassy biomes: linking ecology, human use and conservation. Philosophical Transactions of the Royal Society B: Biological Sciences 371, 20160329.

Leopold, A. (1949). A Sand County Almanac. Oxford University Press, Oxford, UK.

Leteinturier, B., Baker, A.J. M., Bock, L., Matera, J., Malaisse, F. \& Malaise, F. (2001a). Copper and vegetation at the KansanshiJill (Zambia) copper mine. Belgian Foumal of Botany 134, 41-50.

Leteinturier, B., Laroche, J., Matera, J. \& Malaisse, F. (2001b). Reclamation of lead/zinc processing wastes at Kabwe, Zambia : a phytogeochemical approach. South African Fournal of Science 97, 624-627.

Leteinturier, B., Baker, A. J. M. \& Malaisse, F. (1999). Early stages of natural revegetation of metalliferous mine workings in South Central Africa: a preliminary survey. Biotechnologie, Agronomie, Société et Environnement 3, 28-41.

Lippincott, C. L. (2000). Effects of Imperata cylindrica (L.) Beauv. (cogongrass) invasion on fire regime in Florida sandhill (USA). Natural Areas foumal 20, 140-149.

Lockwood, J. L. \& SAmuels, C. L. (2004). Assembly models and the practice of restoration. In Assembly Rules and Restoration Ecology: Bridging the Gap Between Theory and Practice (eds V. M. Temperton, R. J. Hobbs, T. Nuttle and S. Halle), pp. 55-70. Island Press, Washington.

Lunt, I. D., Eldridge, D. J., Morgan, J. W. \& Witt, G. B. (2007). A framework to predict the effects of livestock grazing and grazing exclusion on conservation values in natural ecosystems in Australia. Australian fournal of Botany 55, 401-415.

MACE, G. M. (2014). Whose conservation? Science 345, 1558-1560.

Machado, R. B., Ramos-Neto, M. B., Pereira, P. G. P., Caldas, E. F., Gonçalves, D. A., Santos, N. S., Tabor, K. \& Steininger, M. (2004). Estimativas de perda da área do Cerrado brasileiro. Relatório Técnico Não Publicado, Conservation International do Brasil, Brasília.

Maron, J. L. \& JefFeries, R. L. (2001). Restoring enriched grasslands: effects of mowing on species richness, productivity, and nitrogen retention. Ecological Applications 11, 1088-1100.
Marrs, R. H. (2002). Manipulating the chemical environment of the soil. In Handbook of Ecological Restoration: Volume 1 - Principles of Restoration (eds M. R. Perrow and A. J. Davy), pp. 155-183. Cambridge University Press, Cambridge, UK.

Marshall, A., Williams, N. \& Morgan, J. (2015). Land of Sweeping Plains: Managing and Restoring the Native Grasslands of South-Eastern Australia. Csiro Publishing, Clayton South, Australia.

Maurin, O., Davies, T. J., Burrows, J. E., Daru, B. H., Yessoufou, K., Muasya, A. M., van der Bank, M. \& Bond, W. J. (2014). Savanna fire and the origins of the 'underground forests' of Africa. New Phytologist 204, 201-214.

Mcintyre, S., Heard, K. M. \& Martin, T. G. (2003). The relative importance of cattle grazing in subtropical grasslands: does it reduce or enhance plant biodiversity? 7ournal of Applied Ecology 40, 445-457.

McIntyre, S. \& HobBs, R. (1999). A framework for conceptualizing human effects on landscapes and its relevance to management and research models. Conservation Biology 13, 1282-1292

de Medeiros, M. B. \& Miranda, H. S. (2005). Mortalidade pós-fogo em espécies lenhosas de campo sujo submetido a três queimadas prescritas anuais. Acta Botanica Brasilica 19, 493-500.

Medina, B. M. O. \& Fernandes, G. W. (2007). The potential of natural regeneration of rocky outcrop vegetation on rupestrian field soils in 'Serra do Cipó', Brazil. Brazilian Fournal of Botany 30, 665-678.

Meli, P., Holl, K. D., Benayas, J. M. R., Jones, H. P., Jones, P. G., Montoya, D. \& Mateos, D. M. (2017). A global review of past land use, climate, and active vs. passive restoration effects on forest recovery. PLoS One 12, e0171368.

Mendonça, A. H., Russo, C., Melo, A. C. G. \& Durigan, G. (2015). Edge effects in savanna fragments: a case study in the cerrado. Plant Ecology \& Diversity 8, 493-503.

Middleton, E. L. \& Bever, J. D. (2012). Inoculation with a native soil community advances succession in a grassland restoration. Restoration Ecology 20, 218-226.

Milchunas, D. G., Sala, O. E. \& Lauenroth, W. K. (1988). A generalized model of the effects of grazing by large herbivores on grassland community structure. The American Naturalist 132, 87-106.

Miller, G. H. (2005). Ecosystem collapse in Pleistocene Australia and a human role in megafaunal extinction. Science 309, 287-290.

*Mills, A. J. \& Cowling, R. M. (2006). Rate of carbon sequestration at two thicket restoration sites in the Eastern Cape, South Africa. Restoration Ecology 14, 38-49.

Miranda, H. S., Bustamente, M. M. C. \& Miranda, A. C. (2002). The fire factor. In The Cerrados of Brazil: Ecology and Natural History of a Neotropical Savanna (eds P. S. Oliveira and R. J. Marquis), pp. 51-68. Columbia University Press, New York.

Mistry, J. \& Berardi, A. (2005). Assessing fire potential in a Brazilian savanna nature reserve. Biotropica 37, 439-451.

Mitchell, R. J., Auld, M. H. D., Le Duc, M. G. \& Robert, M. H. (2000). Ecosystem stability and resilience: a review of their relevance for the conservation management of lowland heaths. Perspectives in Plant Ecology, Evolution and Systematics 3, $142-160$.

Mittermeier, R. A., Turner, W. R., Larsen, F. W., Brooks, T. M. \& Gascon, C. (2011). Global biodiversity conservation: the critical role of hotspots. In Biodiversity Hotspots: Distribution and Protection of Conservation Priority Areas (eds F. E. Zachos and J. C. Habel), pp. 3-22. Springer, Heidelberg, Dordrecht, London, New York.

Müller, S. C., Overbeck, G. E., Blanco, C. C., de Oliveira, J. M. \& Pillar, V. D. (2012). South Brazilian forest-grassland ecotones: dynamics affected by climate, disturbance, and woody species traits. In Ecotones between Forest and Grassland (ed. R. W. Myster), pp. 167-187. Springer, New York.

Murcia, G., Aronson, J., Kattan, G. H., Moreno-Mateos, D., Dixon, K. \& Simberloff, D. (2014). A critique of the 'novel ecosystem' concept. Trends in Ecology E Evolution 29, 548-553.

Murphy, B. P. \& Bowman, D. M. J. S. (2012). What controls the distribution of tropical forest and savanna? Ecology Letters 15, 748-758.

Myers, J. A. \& Harms, K. E. (2011). Seed arrival and ecological filters interact to assemble high-diversity plant communities. Ecology 92, 676-686.

Negreiros, D., Fernandes, G. W., Silveira, F. A. O. \& Chalub, G. (2009). Seedling growth and biomass allocation of endemic and threatened shrubs of rupestrian fields. Acta Oecologica 35, 301-310.

Neves, S. P. S. \& Conceição, A. A. (2010). Campo rupestre recém-queimado na Chapada Diamantina, Bahia, Brasil: plantas de rebrota e sementes, com espécies endêmicas na rocha. Acta Botanica Brasilica 24, 697-707.

Nosetto, M. D., Jobbagy, E. G. \& Paruelo, J. M. (2005). Land-use change and water losses: the case of grassland afforestation across a soil textural gradient in Central Argentina. Global Change Biology 11, 1101-1117.

Noss, R. F. (2013). Forgotten Grasslands of the South: Natural History and Conservation. Island Press, Washington D.C.

Noss, R. F., Platt, W. J., Sorrie, B. A., Weakley, A. S., Means, D. B., Costanza, J. \& PeEt, R. K. (2015). How global biodiversity hotspots may go unrecognized: lessons from the North American Coastal Plain. Diversity and Distributions 21, 236-244.

Oliveira, J. M. \& Pillar, V. D. (2004). Vegetation dynamics on mosaics of Campos and Araucaria forest between 1974 and 1999 in Southern Brazil. Community Ecology 5, 197-202.

Oliveira, M., Ogata, R., De Andrade, G. A., Santos, D. d. S., Souza, R., Guimarães, T., da Silva Junior, M. G., Pereira, D. de. S. \& Ribeiro, J. (2012). 
Manual de viveiro e produção de mudas: espécies arbóreas nativas do Cerrado. Universidade de Brasília, Rede de Sementes do Cerrado, Embrapa.

Oliver, T. H., Heard, M. S., Isaac, N.J. B., Roy, D. B., Procter, D., Eigenbrod, F., Freckleton, R., Hector, A., Orme, C. D. L., Petchey, O. L., Proenca, V., Raffaelli, D., Suttle, K. B., Mace, G. M., Martín-López, B., et al. (2015). Biodiversity and resilience of ecosystem functions. Trends in Ecology \& Evolution 30, $673-684$.

Ostertag, T. E. \& Robertson, K. M. (2007). A comparison of native versus old-field vegetation in upland pinelands managed with frequent fire, South Georgia, USA. In Tall Timbers Fire Ecology Conference Proceedings, Bartlesville, OK, USA, pp. 109-120.

Overbeck, G. E., Hermann, J.-M., Andrade, B. O., Boldrini, I. I., Kiehl, K., Kirmer, A., Koch, C., Kollmann, J., Meyer, S. T., Müller, S. C., Nabinger, C., Pilger, G. E., Trindade, J. P. P., Vélez-Martin, E., Walker, E. A., et al. (2013). Restoration ecology in Brazil - time to step out of the forest. Natureza \& Conservação 11, 92-95

Overbeck, G. E., Müller, S. C., Fidelis, A., Pfadenhauer, J., Pillar, V. D., Blanco, C. C., Boldrini, I. I., Both, R. \& Forneck, E. D. (2007). Brazil's neglected biome: the South Brazilian Campos. Perspectives in Plant Ecology, Evolution and Systematics 9, 101-116.

Overbeck, G. E., Müller, S. G., Pillar, V. D. \& Pfadenhauer, J. (2005). Fine-scale post-fire dynamics in southern Brazilian subtropical grassland. Fournal of Vegetation Science 16, 655-664.

Overbeck, G. E., Müller, S. C., Pillar, V. D. \& Pfadenhauer, J. (2006). No heat-stimulated germination found in herbaceous species from burned subtropical grassland. Plant Ecology 184, 237-243.

Overbeck, G. E. \& Pfadenhauer, J. (2007). Adaptive strategies in burned subtropical grassland in southern Brazil. Flora 202, 27-49.

Overbeck, G. E., Vélez-Martin, E., Scarano, F. R., Lewinsohn, T. M., Fonseca, C. R., Meyer, S. T., Müller, S. C., Ceotto, P., Dadalt, L., Durigan, G., Ganade, G., Gossner, M. M., Guadagnin, D. L., Lorenzen, K., JАсовi, C. M., et al. (2015). Conservation in Brazil needs to include non-forest ecosystems. Diversity and Distributions 21, 1455-1460.

Packard, S., Mutel, C. F. \& Jordan, W. R. (2005). The Tallgrass Restoration Handbook: For Prairies, Savannas, And Woodlands. Second New Edition. Island Press, Washington.

Papanastasis, V. P. (2009). Restoration of degraded grazing lands through grazing management: can it work? Restoration Ecology 17, 441-445.

*Pareliussen, I., Olsson, E. G. A. \& Armbruster, W. S. (2006). Factors limiting the survival of native tree seedlings used in conservation efforts at the edges of forest fragments in upland Madagascar. Restoration Ecology 14, 196-203.

Parr, C. L., Gray, E. F. \& Bond, W.J. (2012). Cascading biodiversity and functional consequences of a global change-induced biome switch. Diversity and Distributions $\mathbf{1 8 ,}$ 493-503.

Parr, C. L., Lehmann, C. E. R., Bond, W. J., Hoffmann, W. A. \& Andersen, A. N. (2014). Tropical grassy biomes: misunderstood, neglected, and under threat. Trends in Ecology \& Evolution 29, 205-213.

Parsons, J. J. (1972). Spread of African pasture grasses to the American tropics. fournal of Range Management 25, 12-17.

Pausas, J. G. (2017). Homage to L. M. Coutinho: fire adaptations in cerrado plants. International fournal of Wildland Fire 26, 249-251.

Pausas, J. G., Lamont, B. B., Paula, S., Appezzato-da-Glória, B. \& Fidelis, A. (2018). Unearthing belowground bud banks in fire-prone ecosystems. New Phytologist 217, 1435-1448.

Pena, J. C. C., Goulart, F., Fernandes, G. W., Hoffmann, D., Leite, F. S. F., Britto dos Santos, N., Soares-Filho, B., Sobral-Souza, T., Humberto VANCine, M. \& Rodrigues, M. (2017). Impacts of mining activities on the potential geographic distribution of eastern Brazil mountaintop endemic species. Perspectives in Ecology and Conservation 15, 172-178.

Perrow, M. R. \& Davy, A. J. (2002). Handbook of Ecological Restoration: Volume 2 Restoration in Practice. Cambridge University Press, Cambridge, UK.

*Perry, R. W., Rudolph, D. C. \& Thill, R. E. (2009). Reptile and amphibian responses to restoration of fire-maintained pine woodlands. Restoration Ecology 17, 917-927.

Pilon, N. A. L., Buisson, E. \& Durigan, G. (2018). Restoring Brazilian savanna ground layer vegetation by topsoil and hay transfer. Restoration Ecology 26, 73-81.

Pivello, V. R., Shida, C. N. \& Meirelles, S. T. (1999). Alien grasses in Brazilian savannas: a threat to the biodiversity. Biodiversity and Conservation 8, 1281-1294.

Platt, W. J., Ellair, D. P., Huffman, J. M., Potts, S. E. \& Beckage, B. (2016). Pyrogenic fuels produced by savanna trees can engineer humid savannas. Ecological Monographs 86, 352-372.

*Platt, W. J., Entrup, A. K., Babl, E. K., Coryell-Turpin, G., Dao, V., Hebert, J. A., LaBarbera, C. D., Noto, J. F. L., Ogundare, S. O., Stamper, L. K. \& Timilsina, N. (2015). Short-term effects of herbicides and a prescribed fire on restoration of a shrub-encroached pine savanna. Restoration Ecology 23, 909-917.

Platt, W. J. \& GotTschalk, R. M. (2001). Effects of exotic grasses on potential fine fuel loads in the groundcover of South Florida slash pine savannas. International Journal of Wildland Fire 10, 155-159.
Poschlod, P., Kiefer, S., Tränkle, U., Fischer, S. \& Bonn, S. (1998). Plant species richness in calcareous grasslands as affected by dispersability in space and time. Applied Vegetation Science 1, 75-91.

Provencher, L., Herring, B. J., Gordon, D. R., Rodgers, H. L., Galley, K. E. M., Tanner, G. W., Hardesty, J. L. \& Brennan, L. A. (2001). Effects of hardwood reduction techniques on longleaf pine sandhill vegetation in Northwest Florida. Restoration Ecology 9, 13-27.

Ramos-Neto, M. B. \& Pivello, V. R. (2000). Lightning fires in a Brazilian savanna National Park: rethinking management strategies. Environmental Management 26, 675-684.

Ratnam, J., Bond, W. J., Fensham, R. J., Hoffmann, W. A., Archibald, S., Lehmann, C. E. R., Anderson, M. T., Higgins, S. I. \& Sankaran, M. (2011). When is a 'forest' a savanna, and why does it matter? Global Ecology and Biogeography 20, 653-660.

Ratnam, J., Tomlinson, K. W., Rasouinha, D. N. \& Sankaran, M. (2016). Savannahs of Asia: antiquity, biogeography, and an uncertain future. Philosophical Transactions of the Royal Society B: Biological Sciences 371, 20150305.

Ratter, J. A., Ribeiro, J. F. \& Bridgewater, S. (1997). The Brazilian Cerrado vegetation and threats to its biodiversity. Annals of Botany 80, 223-230.

Reever Morghan, K. J. \& Seastedt, T. R. (1999). Effects of soil nitrogen reduction on nonnative plants in restored grasslands. Restoration Ecology 7, 51-55.

Reis, J., Rodrigues, R., Conceição, M. \& Martins, C. (2016). Integração Lavoura-Pecuaria-Floresta no Brasil: uma estratégia de agricultura sustentável baseada nos conceitos da Green Economy Initiative. Sustentabilidade em Debate 7, 58-73.

Resende, F. M., Fernandes, G. W. \& Coelho, M. S. (2013). Economic valuation of plant diversity storage service provided by Brazilian rupestrian grassland ecosystems. Brazilian fournal of Biology 73, 709-716.

Ribeiro, M. C. \& Figueira, J. E. G. (2011). Uma abordagem histórica do fogo no Parque Nacional da Serra do Cipó, Minas Gerais - Brasil. Biodiversidade Brasileira 1, $212-227$

Riginos, G., Porensky, L. M., Veblen, K. E., Odadi, W. O., Sensenig, R. L., Kimuyu, D., Keesing, F., Wilkerson, M. L. \& YounG, T. P. (2012). Lessons on the relationship between livestock husbandry and biodiversity from the Kenya long-term Exclosure Experiment (KLEE). Pastoralism: Research, Policy and Practice 2, 10 .

Rissi, M. N., Baeza, M. J., Gorgone-Barbosa, E., Zupo, T. \& Fidelis, A. (2017). Does season affect fire behaviour in the Cerrado? International fournal of Wildland Fire 26, 427-433.

*Rosales, J., Cuenca, G., Ramírez, N. \& De Andrade, Z. (1997). Native colonizing species and degraded land restoration in La gran Sabana, Venezuela. Restoration Ecology 5, 147-155.

Rossiter, N. A., Setterfield, S. A., Douglas, M. M. \& Hutley, L. B. (2003). Testing the grass-fire cycle: alien grass invasion in the tropical savannas of northern Australia. Diversity and Distributions 9, 169-176.

*Ruckman, E. M., Schwinning, S. \& Lyons, K. G. (2012). Effects of phenology at burn time on post-fire recovery in an invasive C4 grass. Restoration Ecology 20 $756-763$.

Russell-Smith, J., Сook, G. D., Cooke, P. M., Edwards, A. C., Lendrum, M., Meyer, C. (Mick) \& Whitehead, P. J. (2013). Managing fire regimes in north Australian savannas: applying Aboriginal approaches to contemporary global problems. Frontiers in Ecology and the Environment 11, e55-e63.

*SaAd, L., Parmentier, I., Colinet, G., Malaisse, F., Faucon, M.-P., Meerts, P. \& Maнy, G. (2012). Investigating the vegetation-soil relationships on the copper-cobalt rock outcrops of Katanga (D. R. Congo), an essential step in a biodiversity conservation plan. Restoration Ecology 20, 405-415.

Sampaio, A. B., Vieira, D. L. M., Cordeiro, A. O. de. O., Aquino, F. de. G., Sousa, A. de. P., de Albuquerque, L. B., Schmidt, I. B., Ribeiro, J. F., Pellizaro, K. F., de Sousa, F. S., Moreira, A. G., dos Santos, A. B. P., Rezende, G. M., Silva, R. R. P., Alves, M., et al. (2015). Guia de restauraçãa do Cerrado, Volume 1 Semeadura Direta, la edição - Brasília - 2015. Embrapa, Universidade de Brasília, Rede de Sementes do Cerrado.

Savadogo, P., Tigabu, M., Sawadogo, L. \& Odén, P. C. (2009). Examination of multiple disturbances effects on herbaceous vegetation communities in the Sudanian savanna-woodland of West Africa. Flora 204, 409-422.

Savadogo, P., Tiveau, D., Sawadogo, L. \& Tigabu, M. (2008). Herbaceous species responses to long-term effects of prescribed fire, grazing and selective tree cutting in the savanna-woodlands of West Africa. Perspectives in Plant Ecology, Evolution and Systematics 10, 179-195.

Sawadogo, L., Tiveau, D. \& NygÅRd, R. (2005). Influence of selective tree cutting, livestock and prescribed fire on herbaceous biomass in the savannah woodlands of Burkina Faso, West Africa. Agriculture, Ecosystems \& Environment 105, 335-345.

Schmidt, I. B., Fidelis, A., Miranda, H. S. \& Ticktin, T. (2017). How do the wets burn? Fire behavior and intensity in wet grasslands in the Brazilian savanna. Brazilian fournal of Botany 40, 167-175.

Schmidt, I. B., Moura, L. C., Ferreira, M. C., Eloy, L., Sampaio, A. B., Dias, P. A. \& Berlinck, C. N. (2018). Fire management in the Brazilian savanna: first steps and the way forward. Fournal of Applied Ecology 55, 2094-2101. 
Scott, K., Setterfield, S. A., Douglas, M. M., Parr, C. L., Schatz, J. \& Andersen, A. N. (2012). Does long-term fire exclusion in an Australian tropical savanna result in a biome shift? A test using the reintroduction of fire. Austral Ecology $37,693-711$.

Searchinger, T. D., Estes, L., Thornton, P. K., Beringer, T., Notenbaert, A., Rubenstein, D., Heimlich, R., Licker, R. \& Herrero, M. (2015). High carbon and biodiversity costs from converting Africa's wet savannahs to cropland. Nature Climate Change 5, 481-486.

SER Working Group (2004). The SER International Primer on Ecological Restoration; Society for Ecological Restoration International Science \& Policy Working Group. www.ser.org \&. Society for Ecological Restoration International, Tucson.

Setterfield, S. A., Rossiter-Rachor, N. A., Hutley, L. B., Douglas, M. M. \& Williams, R. J. (2010). Turning up the heat: the impacts of Andropogon gayanus (gamba grass) invasion on fire behaviour in northern Australian savannas. Diversity and Distributions 16, 854-861.

*Shepherd, B. J., Miller, D. L. \& Thetford, M. (2012). Fire season effects on flowering characteristics and germination of longleaf pine (Pinus palustris) savanna grasses. Restoration Ecology 20, 268-276.

*Shiels, A. B., Medeiros, A. C. \& von Allmen, E. I. (2017). Shifts in an invasive rodent community favoring black rats (Rattus rattus) following restoration of native forest. Restoration Ecology 25, 759-767.

Shutcha, M. N., Mubemba, M. M., Faucon, M.-P., Luhembwe, M. N., Visser, M., Colinet, G. \& Meerts, P. (2010). Phytostabilisation of copper-contaminated soil in Katanga: an experiment with three native grasses and two amendments. International Fournal of Phytoremediation 12, 616-632.

Silcock, R. G. \& Scattini, W. J. (2007). The original native pasture ecosystems of the eastern and western Darling Downs - can they be restored? Tropical Grasslands 41, 154 .

Silva, J. P., Toland, J., Jones, W., Eldridge, J., Thorpe, E. \& O'Hara, E. (2008). LIFE and Europe's Grasslands - Restoring a Forgotten Habitat. European Communities, Belgium.

*Silva, R. R. P., Oliveira, D. R., Da Rocha, G. P. E. \& Vieira, D. L. M. (2015). Direct seeding of Brazilian savanna trees: effects of plant cover and fertilization on seedling establishment and growth. Restoration Ecology 23, 393-401.

Silveira, F. A. O., Negreiros, D., Barbosa, N. P. U., Buisson, E., Carmo, F. F., Carstensen, D. W., Conceição, A. A., Cornelissen, T. G., Echternacht, L., Fernandes, G. W., Garcia, Q. S., Guerra, T. J., Jacobi, C. M., Lemos-Filho, J. P., Stradic, S. L., et al. (2016). Ecology and evolution of plant diversity in the endangered campo rupestre: a neglected conservation priority. Plant and Soil 403, $129-152$.

Simon, M. F., Grether, R., de Queiroz, L. P., Skema, C., Pennington, R. T. \& Hughes, C. E. (2009). Recent assembly of the Cerrado, a neotropical plant diversity hotspot, by in situ evolution of adaptations to fire. Proceedings of the National Academy of Sciences of the United States of America 106, 20359-20364.

Simpson, K. J., Ripley, B. S., Christin, P.-A., Belcher, C. M., Lehmann, C. E. R., Thomas, G. H. \& Osborne, C. P. (2016). Determinants of flammability in savanna grass species. Fournal of Ecology 104, 138-148.

*Slocum, M. G., Platt, W. J. \& Cooley, H. C. (2003). Effects of differences in prescribed fire regimes on patchiness and intensity of fires in subtropical savannas of Everglades National Park, Florida. Restoration Ecology 11, 91-102.

Smit, I. P. J., Asner, G. P., Govender, N., Vaughn, N. R. \& van Wilgen, B. W. (2016). An examination of the potential efficacy of high-intensity fires for reversing woody encroachment in savannas. Fournal of Applied Ecology 53, 1623-1633.

Sonter, L. J., Barrett, D. J., Soares-Filho, B. S. \& Moran, C. J. (2014). Global demand for steel drives extensive land-use change in Brazil's Iron Quadrangle. Global Environmental Change 26, 63-72.

Staver, A. C., Archibald, S. \& Levin, S. A. (2011). The global extent and determinants of savanna and forest as alternative biome states. Science 334, $230-232$.

Stevens, J. T. \& Beckage, B. (2009). Fire feedbacks facilitate invasion of pine savannas by Brazilian pepper (Schinus terebinthifolius). New Phytologist 184, 365-375.

Stevens, N., Erasmus, B. F. N., Archibald, S. \& Bond, W. J. (2016). Woody encroachment over 70 years in South African savannahs: overgrazing, global change or extinction aftershock? Philosophical Transactions of the Royal Society B: Biological Sciences 371, 20150437

Strassburg, B. B. N., Brooks, T., Feltran-Barbieri, R., Iribarrem, A., Crouzeilles, R., Loyola, R., Latawiec, A. E., Filho, F. J. B. O., Scaramuzza, C. A. de. M., Scarano, F. R., Soares-Filho, B. \& Balmford, A. (2017). Moment of truth for the Cerrado hotspot. Nature Ecology \& Evolution 1, 0099.

Suding, K., Higgs, E., Palmer, M., Callicott, J. B., Anderson, C. B., Baker, M., Gutrich, J. J., Hondula, K. L., LaFevor, M. C. \& Larson, B. M. (2015). Committing to ecological restoration. Science 348, 638-640.

Suding, K. N., Gross, K. L. \& Houseman, G. R. (2004). Alternative states and positive feedbakcs in restoration ecology. Trends in Ecology and Evolution 19, 46-53.

Thomas, P. A. (2017). Restauração ecológica em campos invadidos por Urochloa decumbens nos Campos Sulinos. MSc Thesis: Universidade Federal do Rio Grande do Sul, Porto Alegre.
Torchelsen, F. P., Cadenazzi, M. \& Overbeck, G. E. (2018). Do subtropical grasslands recover spontaneously after afforestation? Fournal of Plant Ecology rty011. Török, K., Szili-Kovàcs, T., Halassy, M., Toth, T., Hayek, Z., Paschke, M. K. \& WARDELL, L. J. (2000). Immobilization of soil nitrogen as a possible method for the restoration of sandy grassland. Applied Vegetation Science 3, 7-14.

Török, P., Vida, E., DeÁk, B., Lengyel, S. \& Tóthmérész, B. (2011). Grassland restoration on former croplands in Europe: an assessment of applicability of techniques and costs. Biodiversity and Conservation 20, 2311-2332.

Trauernicht, C., Murphy, B. P., Portner, T. E. \& Bowman, D. M. J. S. (2012). Tree cover-fire interactions promote the persistence of a fire-sensitive conifer in a highly flammable savanna. Fournal of Ecology 100, 958-968.

Trauernicht, G., Murphy, B. P., Tangalin, N. \& Bowman, D. M. J. S. (2013). Cultural legacies, fire ecology, and environmental change in the Stone Country of Arnhem Land and Kakadu National Park, Australia. Ecology and Evolution 3, 286-297.

Twidwell, D., Rogers, W. E., Fuhlendorf, S. D., Wonkka, C. L., Engle, D. M., Weir, J. R., Kreuter, U. P. \& TAylor, C. A. (2013). The rising Great Plains fire campaign: citizens' response to woody plant encroachment. Frontiers in Ecology and the Environment 11, e64-e71.

Uys, R. G., Bond, W. J. \& Everson, T. M. (2004). The effect of different fire regimes on plant diversity in southern African grasslands. Biological Conservation 118, $489-499$.

Van Langevelde, F., Van De Vijver, C. A. D. M., Kumar, L., Van De Koppel, J., De Ridder, N., Van Andel, J., Skidmore, A. K., Hearne, J. W., Stroosnijder, L., Bond, W. J., Prins, H. H. T. \& Rietkerk, M. (2003). Effects of fire and herbivory on the stability of savanna ecosystems. Ecology 84, 337-350.

*Varner, J. M., Gordon, D. R., Putz, F. E. \& Hiers, J. K. (2005). Restoring fire to long-unburned Pinus palustris ecosystems: novel fire effects and consequences for long-unburned ecosystems. Restoration Ecology 13, 536-544.

Veldman, J. W. (2016). Clarifying the confusion: old-growth savannahs and tropical ecosystem degradation. Philosophical Transactions of the Royal Society B: Biological Sciences 371, 20150306.

Veldman, J. W., Brudvig, L. A., Damschen, E. I., Orrock, J. L., Mattingly, W. B. \& WALker, J. L. (2014). Fire frequency, agricultural history and the multivariate control of pine savanna understorey plant diversity. Fournal of Vegetation Science 25, 1438-1449.

Veldman, J. W., Buisson, E., Durigan, G., Fernandes, G. W., Le Stradic, S., Mahy, G., Negreiros, D., Overbeck, G. E., Veldman, R. G., Zaloumis, N. P., Putz, F. E. \& Bond, W. J. (2015a). Toward an old-growth concept for grasslands, savannas, and woodlands. Frontiers in Ecology and the Environment 13, 154-162.

Veldman, J. W., Overbeck, G. E., Negreiros, D., Mahy, G., Le Stradic, S., Fernandes, G. W., Durigan, G., Buisson, E., Putz, F. E. \& Bond, W. J. $(2015 b)$. Where tree planting is bad for biodiversity and ecosystem services. Bioscience 65, 1011-1018.

Veldman, J. W., Mattingly, W. B. \& Brudvig, L. A. (2013). Understory plant communities and the functional distinction between savanna trees, forest trees, and pines. Ecology 94, 424-434.

Vieira, M. de. S., Bonilha, C. L., Boldrini, I. I., Overbeck, G. E. (2015). The seed bank of subtropical grasslands with contrasting land-use history in southern Brazil. Acta Botanica Brasilica 29, 543-552.

Walker, J. L. \& Silletti, A. M. (2006). Restoring the ground layer of longleaf pine ecosystems. In The Longleaf Pine Ecosystem (eds S. Jose, E. J. Jokela and D. L. Miller), pp. 297-333. Springer, New York.

Waters, C., Whalley, W. \& Huxtable, C. (2001). Grassed up - Guidelines for Revegetating with Australian Native Grasses. NSW Agriculture, Orange, Australia.

Weigl, P. D. \& KNowles, T. W. (2014). Temperate mountain grasslands: a climate-herbivore hypothesis for origins and persistence. Biological Reviews 89, 466-476.

White, P. S. \& Jentsch, A. (2004). Disturbance, succession and community assembly in terrestrial plant communities. In Assembly Rules and Restoration Ecology: Bridging the Gap Between Theory and Practice (eds V. M. Temperton, R. J. Hobbs, T. Nuttle and S. HALLE), pp. 342-366. Island Press, Washington.

White, R., Murray, S. \& Rohweder, M. (2000). Pilot Analysis of Global Ecosystems: Grassland Ecosystems. World Resources Institute, Washington D.C.

Wiens, D. \& Slaton, M. R. (2012). The mechanism of background extinction. Biological Journal of the Linnean Society 105, 255-268.

Wiley (2017). Wiley online library. Available at: http://onlinelibrary.wiley.com/ advanced/search. Accessed 25.09.2017.

*Willcox, E. V. \& Giuliano, W. M. (2012). Roller chopping effectively reduces shrub cover and density in pine flatwoods. Restoration Ecology 20, 721-729.

Wilsey, B. J., Martin, L. M. \& Kaul, A. D. (2018). Phenology differences between native and novel exotic-dominated grasslands rival the effects of climate change. Journal of Applied Ecology 55, 863-873.

WiLson, S. D. (2002). Prairies. In Handbook of Ecological Restoration. Volume 2 - Restoration in Practice (eds M. R. Perrow and A. J. DAvy), pp. 443-465. Cambridge University Press, Cambridge, UK.

Wilson, S. D. \& GERRY, A. K. (1995). Strategies for mixed-grass prairie restoration: herbicide, tilling, and nitrogen manipulation. Restoration Ecology 3, 290-298. 
Wiseman, R., Morris, C. D., Granger, J. E. \& Cowling, R. M. (2002). Effects of pre-planting treatments on the initial establishment success of indigenous grass seedlings planted into a degraded Aristida junciformis-dominated grassland. South African Fournal of Botany 68, 362-369.

Wittenberg, R. \& Cock, M. J. W. (2001). Invasive Alien Species: A Toolkit of Best Prevention and Management Practices. CABI, Wallingford.

*Yelenik, S. G. (2017). Linking dominant Hawaiian tree species to understory development in recovering pastures via impacts on soils and litter. Restoration Ecology $25,42-52$.

Zaloumis, N. P. (2013). South African grassland ecology and its restoration. MS. Thesis: University of Cape Town.

Zaloumis, N. P. \& Bond, W. J. (2011). Grassland restoration after afforestation: no direction home? Austral Ecology 36, 357-366.

Zaloumis, N. P. \& Bond, W. J. (2016). Reforestation or conservation? The attributes of old growth grasslands in South Africa. Philosophical Transactions of the Royal Society B: Biological Sciences 371, 20150310.

Zlinszky, A., Heilmeier, H., Balzter, H., Czúcz, B. \& Pfeifer, N. (2015). Remote sensing and GIS for habitat quality monitoring: new approaches and future research. Remote Sensing 7, 7987-7994.
Zupo, T., BaEza, M. J. \& Fidelis, A. (2016). The effect of simulated heat-shock and daily temperature fluctuations on seed germination of four species from fire-prone ecosystems. Acta Botanica Brasilica 30, 514-519.

\section{SUPPORTING INFORMATION}

Additional supporting information may be found online in the Supporting Information section at the end of the article.

Appendix S1. Literature search in Restoration Ecology.

Table S1. Results of literature search in Restoration Ecology.

Figure S1. Approximate distribution of disturbancedependent tropical and subtropical old-growth grasslands, including savannas, open-canopy woodlands, and grassland-forest mosaics.

(Received 5 March 2018; revised 27 August 2018; accepted 30 August 2018 ) 